\title{
STAGE OF HISTORICAL EVOLUTION OF PRIVATE VEHICLE OWNERSHIP IN THE CITY OF BARCELONA
}

\author{
Fernando Pérez Diez \\ $\mathrm{PhD}$ student in Civil Engineering \\ Universitat Politècnica de Catalunya \\ José Magín Campos Cacheda \\ $\mathrm{PhD}$ in Civil Engineering \\ Professor de la Universitat Politècnica de Catalunya \\ Julià Cabrerizo Sinca \\ $\mathrm{PhD}$ student in Civil Engineering \\ Universitat Politècnica de Catalunya
}

\begin{abstract}
Transport demand and private motor vehicle ownership (cars and motorcycles) are generally related to the socio-economic development, increasing urbanization, public policies and rising per capita income.

Private motor vehicle ownership varies between countries and geographical regions. However, it tends to have some common patterns in its historical evolution. So that during the early stages of development, the rate of motorization increased mainly by acquisitions of PTWs (mopeds and motorcycles). As the economy grows, the increase in per capita income stimulates a shift from PTWs to cars, which are preferred for their safety, versatility, comfort and social status. The increasing use of cars contributes to raising travel costs (congestion, parking constraints, accidents, pollution), that coupled with public policies to discourage car use, tends to favour modal shifts from cars to public transport and in some regions also to PTWs.
\end{abstract}

This study analyze the historical evolution of private motor vehicle ownership in Spain (cars and motorcycles), and identify the stage in which is the city of Barcelona, characterized by the high use of PTWs. The increase use of PTWs is a common phenomenon in some major European cities and suggests a continuous future growth in developed countries and congested urban areas, that is not in line with the assumptions of some models, which predict that in the long-run there will be a decrease in use of PTWs with high income per capita levels. 


\section{INTRODUCTION}

Mobility provides access to people, goods, services and information, favoring human development and socio-economic activities. The more efficient mobility becomes, the greater socio-economic prosperity and quality of life tend to be.

Transport is a factor of social inclusion because the provision of affordable accessibility to the population allows individuals to participate in work, education and community activities. Poor transport options can reinforce social exclusion. Policy makers must provide safe, affordable, convenient and reliable mobility and accessibility to the whole population through sustainable and environmentally friendly access to transport systems.

Mobility in motor vehicles consists of journeys made by public transport and in private vehicles, mainly cars and powered two wheelers (motorcycles and mopeds). Understanding the patterns of the historic evolution of motor vehicle ownership is useful to forecast and manage transport demand, planning infrastructures, urban design, implementation and assessing of transport programs and policies, so that social welfare is maximized.

Knowledge about patterns on vehicle ownership plays an important role in the overall transportation planning process. Forecasts about evolution of motorization are important over a wide variety of public and private aspects such as economic system, energy consumption, environment, public health and so on. Transport modeling and forecasting demand can assist in investment decision-making, designing Policy measures, predicting the use of present and future infrastructure, needs of regulation and energy consumption.

Private motor vehicle ownership varies between countries and geographic regions. However it tends to have some common patterns in their historical evolution. Much of the existing literature shows the impact of changing levels of economic activity on mobility rates and traffic volumes. Policymakers should consider the effects of economic cycles on mobility evolution to manage the effects.

Knowledge on the socio economic variables that shape private motor vehicle ownership evolution and the interactions among different types of vehicle ownership is useful in transport management, infrastructure planning, road safety and public policies, helping to maintain consistent perspectives on dealing with urban transportation problems. Knowing how other similar urban areas have gone through the stages, the kind of policies implemented and their results can be a useful reference when deciding what kind of measures should be implemented.

This study has been conducted to identify the stage of historical evolution of private motor vehicle ownership in which the city of Barcelona is at, identifying factors underlying the mode choices behavior, characterized by the high use of the powered two wheelers. 


\section{PATTERNS OF HISTORICAL EVOLUTION OF PRIVATE VEHICLE OWNERSHIP.}

The bases of economy are transactions involving movements of persons, goods and information. Transportation is a central component that allows people to accomplish activities located in different places. The wants and needs of people drive transportation demand. As the economy grows the number and distances of movements shifting towards motorized transport modes increases, therefore transportation is closely linked with economic development.

The historical evolution of private vehicle ownership is determined by different types of variables that have relative importance according to the stage of evolution. Motor vehicle ownership determines travel behavior. There are several patterns that allow study, model and even forecast car and motorcycle historical evolution, mostly related with socioeconomic factors. (de JONG, G et al. 2004).

Economic factors and evolution of per capita income are closely associated with a rise in traffic volumes and vehicle possession and use. In the literature of mode choice modeling several studies has emphasized the influence of income and household car and motorcycle ownership. The income level changes consumer preferences over modes of transport. (PONGTHANAISAWAN, J.; SORAPIPATANA, Ch. 2010).

The concept of "stable daily travel time" and proportion of budgets that on average each person spends on traveling each day implies that when income rises, mobility rises in proportion, but time remains similar. In this way, rising income implies rising demand for mobility. When budget increase devoting the same daily time to travel, is necessary to use faster modes of transport to cover greater distances within the same fixed travel time. This way an increase in income is linked to the evolution to faster and efficient means of transportation. (SCHAFER, A.; VICTOR, D.G., 2000).

Modal choice is closely related to the concept of "Transportation Affordability" measured by the type and number of vehicles that a household can afford depending on the household's income level, related to direct costs such as owning and driving vehicles, and the indirect costs such as parking and consumption in comparison with the quality and costs of alternative modes of transportation. (LITMAN, T. 2015).

Private vehicle ownership influences mobility and mobility in turn leads to a decision to acquire or dispose of a car. Because this interactive relationship evolves over time, incorporating dynamism into the analysis is of extreme importance (KITAMURA, R. 1988). A factor that also affects the historical evolution of the private vehicle ownership is how much powered two wheelers are involved in mobility. In some countries (especially in East Asia), while per capita incomes remains at low levels, possession of motorcycles increases through greater affordability, outnumbering car ownerships (surpassing the number of cars). 
In these countries PTW are useful especially in urban areas for convenient parking, low prices and competitive operating costs. (HSU, TP. 2005).

Many factors affect the evolution of car ownership, such as income (total expenditure), the level of urbanization, and alternative means of transport. These factors cause variations in the evolution. Income is the primary factor of evolution of car ownership, especially in the first stages, decreasing when higher levels of car ownership are reached. (DARGAY, J. and GATELY, D. 2009).

Economic growth leads to an increase of mobility demands and vehicle ownership, car ownership tends to increase as per capita GDP grows (SCHAFER, A ; VICTOR, D.G., 2006). Walking is the world's dominant mode of transport, until a certain threshold of individual wealth is reached; people can afford to buy vehicles encouraging shifts from nonmotorized to motorized transport modes (SCHAFER, A., 2006). At an early stage bicycles are used for short trips, being replaced by motorcycles that allow making longer trips. After personal income grows up to a certain level, people will shift from motorcycle to car ownership.

With increasing wealth and society increases its levels of urbanization, people begin to be able to afford to buy cars that tend to replace the motorcycle for longer journeys with greater urban component. As wealth continues to grow and the levels of urbanization increase, urban environments experience congestion caused by the increasing number of cars. As a country evolves socio-economically, the income of individuals and the levels of urbanization tend to increase and the provision of better infrastructures improve traffic conditions.

When high levels of car travels are achieved, improvements in infrastructure and traffic management become insufficient and the problems related to congestion are widespread. At this stage public authorities tend to introduced schemes to discourage the car use that as collateral effects tends to make the use of the PTWs more attractive, producing a reduction in the use of cars and an increase in the use of motorcycles in dense urban environments, where even policy makers encourage the use of bikes for short distance trips.

When countries reach a high level of per capita income and social development, people have more economic resources and enjoy more spare time to practice a wide range of leisure activities. At this stage motorcycles are a usual mean of transportation to access places where they can practice spare time activities, and are even ridden simply for recreational purposes (touring, cruising, running errands...).

The historical evolution is thus marked by different income, social and even cultural thresholds that once surpassed tend to boost modal split, from bikes to motorcycles, from motorcycles to cars and finally from cars to motorcycles and even bikes. It is possible to identify a way that developed countries have already experienced this and it can be foreseen 
how other countries will probably evolve.

High levels in private vehicle ownership are the result of a long historical process of socioeconomic and urban development, encompassed with a wide range of policies regulating private vehicle use.

There are three important phenomena when analyzing the behavior of the evolution of car ownership: the elasticity at low income levels, the inelasticity when high income and socioeconomic levels are reached (saturation ceiling) and a hysteresis loop back, in the way that car ownership does not respond symmetrically to rising and falling income (DARGAY, J.M. 2001).

\section{1 Early stages of development.}

During the early stages of development, the rate of motorization increases at the pace of economic growth. The increase of income per capita allows a shift of the demand from cheaper vehicles as bikes to motorized ones. Access to motorized vehicle ownership is mainly achieved through PTWs: mopeds and motorcycles.

The first stages of evolution of urban mobility and hence private vehicle ownership, tends to accelerate when societies develop their industrial sectors and the demand of workforce pushes the phenomenon of migration from rural to urban industrialized areas.

Economic activity encourages population concentrations, growing according on the monocentric land use city model formulated by ALONSO, W. (1964). The model was broadened with the formulation of equilibrium models, over the basis that population densities would decrease negative exponentially with distance outwards from the city centre (CBD). Density is proportional to the inverse of the distance which is supposed to represent the disutility of commuting (MILLS, E. 1967, and 1972; MUTH, R. 1969). Transportation infrastructures and systems have implications shaping the spatial structure of the cities, generating different economic, environmental and social effects. Differences in accessibility, transport and commuting cost within an urban area are balanced by differences in the price of living space (BRUECKNER, J.K 1987; ANAS, A. et al 1998).

At early stage of economic development, public transport offer is poor and infrastructures are deficient, but the smaller cities and major density enables short trips, able to be done walking. As income stays low, bicycles are the only private vehicle affordable, then PTWs as relatively cheap vehicles, useful for a wide variety of uses, from working vehicle, transport, delivery to even leisurely activities. (LEE, T-Ch. et al. 2011). In more advanced stages of developed PTWs, appears as a reliable solution to inner-city mass transportation problems. Car possession stays low and motorcycles increase through greater affordability at the pace of economic growths. 
In many Developed countries motorcycles are a primary mode of transportation, especially in urban areas. In 1996 the total number of PTW registered in India represented the $69 \%$ of the total number of motor vehicles, in Germany the $5 \%$, in U.S.A 1,8 \% and in Japan $18 \%$ (MOHAN, D. 2002). At this stage there is high elasticity between vehicle ownership and income. GAKENHEIMER, R (1999) found that cars per 1000 population correlates very well $\left(\mathrm{R}^{2}=0,71\right)$ with the annual income of the top $20 \%$ of population of a large group of low income developing countries (Bangladesh, India, Pakistan, Ghana, Sri Lanka, Indonesia, Philippines, Ivory Coast, Guatemala, Morocco, Peru, and Colombia).

\subsection{Shift form motorcycle to car ownership.}

Economic growth tends to stimulate higher levels of consumption. When the gradual increase in per capita income reaches a threshold level, car is one of the assets that people wants to buy once they have covered the basic needs. Higher income correlates with higher car ownership and use. The affordability of buying cars encourages a shift of use from motorcycles to cars. The substitution effect from motorcycles to cars is possible because the overall income increase reduces the costs of buying and running a car. (LAW, T. H. et al. 2015).

Income rise favors a switch from PTWs to cars. When the income per capita growth trespasses a certain level over the car owning threshold, is therefore expected a decline in motorcycle ownership. NISHITATENO, S. and BURKE, P.J (2014) analyzed data from 153 countries for the period 1963-2010 and found that the number of PTWs per capita increases as income per capita grows until it reaches a threshold of around $\$ 8,000$ per person per year. From this threshold on, in spite of income increase, the possession of PTWS decreases. Cars tend to be preferred due to the independence that they provide mobility, safety, versatility, convenience, comfort and also because cars are regarded as a symbol of status, a badge of social welfare (GOODWIN, P.B. 1997; STRADLING, S. G. et al 1999; STEG, L et al. 2001; STEG, L. 2005). Their high utility and symbolic appeal stimulates car ownership, even if public transport is well prepared as an alternative. (WU, G et al. 1999; STEG, L. 2003).

As the economy grows, the capita income tends to increase gradually and hence the affordability of cars acquisition. Simultaneously socio-economic growth tends to be accompanied by an improvement of transport services, both in quantity and quality of infrastructures and the offer of public transport. The increased accessibility in public and private transport, with smaller costs (in time and money) favors the growth of the peripheral areas, where it is possible to live more cheaply and in spacious homes, far from the center and workplace. Distant areas from center town are more affordable, and with the improvement in transport become more accessible in time and cost. Better accessibility makes appear a phenomenon named suburbanization, consisting in urban expansion occurring with the growth of less dense peripheral areas. Transportation improvements cause suburbanization, fostering population growth in suburban areas, while transport infrastructure affects urban form causing the population to spread out along the highways 
(BAUM-SNOW, N. 2007). Suburbanization is related with increase of car-ownership in peripheral areas where the public transport offer is scarce, and lesser densities produce that despite trips become longer, average travel speeds are faster, favoring the use of the car for commuting. (MIESZKOWSKI, P. and MILLS, E. 1993; MONCLÚS, F.J. 1998; GALSTER, G., et al. 2001;FISHMAN, R. 2008; GUERRA, E. 2015).

Technological innovation and governmental backing to the car industry could reduce the cost of vehicle acquisition and accelerate the motorization process. As most of the countries in USA initially motorcycles were more affordable vehicles than cars. The shift form motorcycle to car ownership was strongly pushed through technological and organizational innovations introduced by Henry Ford from 1907 on mass production of automobiles making "Model T" an affordable automobile and a "dominant design" (ABERNATHY, W. J. and UTTERBACK, J M. 1978). By the mid-1920s the cost of motorcycles as Harley or Indian was around \$275-\$375, and the price of a Model T Ford was only \$545 (DULANEY, W.L. 2005). There are similar effects in vehicle producing countries as now India and China, where despite the cost of motorcycles is low, improvements in production and support for the car industry significantly reduces the price of automobiles and drives an increase in motorization (HUO, H., et al. 2007; SCHUSTER, T. and HOLTBRÜGGE, D. 2011; TIWARI, R. and HERSTATT, C. 2014; VERMA, M.. 2014). Something similar happens in Vietnam with motorcycles, where domestic assemblers, manufacturers and suppliers of parts and components of low-priced models have boost the sales and popularity of motorcycles (FUJITA, M.. 2014).

The risk factor encourages the shift from motorcycle to car ownership and usage in many developed countries. PTWs are a relatively risky form of transport. The limited protection design of motorcycles implies that are less secure in comparison to the protection of an enclosed vehicle as cars. PTW occupants are more likely to be injured or killed in accidents. A parameter for quantifying risk exposure is death in accident depending on the mileage (accidents per Vehicle-Kilometers Travelled VKT). PTW displacements in all 25 EU countries in 2006 accounted for $2 \%$ of total kilometers traveled, while PTW users representing $16 \%$ of all road deaths (ETSC 2007). In Britain the ratio of deaths for riders is 24 times higher than for car occupants (DEPARTMENT FOR TRANSPORT 2015). In the USA the ratio of motorcyclists dead by VKT was 30 times more likely than car occupants (NHTSA 2013); In Sweden is about 20 times higher (SRA 2008), in Denmark 12 times, in Belgium and Canada 13 times, in Australia 14 times, in Netherlands 20 times, in Ireland and Czech Republic 24 times (IRTAD 2014). Some studies suggest that a part of motorcyclists shift towards car as a safer mode of transport when improve their income (STEVENSON, M. and HARIZA, A. 2006). 


\subsection{Car Saturation level. Increase of motorcycle use.}

When societies reach high per capita GDP and large urbanization levels, tend to have a higher motorization. This is a mature stage where a large part of population could have higher incomes, varied and sophisticated needs and more leisure time. A large range of trip purposes is satisfied with a wide accessibility by public and private means of transportation, and hence could explain some changing consumer preferences over modes of transport.

In advanced stages of development, the rate of motorization tends to reach a saturation level, shifting from an expansion market to a mature one. When this stage is reached, in dense urban areas, modal split is increased, and motorization stabilizes while car ownership gets reduced (MOGRIDGE, M. J. H. 1967). The saturation level could be measured by the number of car ownership per 1,000 inhabitants, and varies depending on the type of society, level of development and geographical and urbanization factors. WHELAN et al. (2000) analyzed the limits to car ownership growth. Some other studies consider that vehicle saturation levels may be different across countries, as a function of population density, and then it is possible to estimate empirically the saturation rate for different countries, considering income elasticity's. (DARGAY, J. and GATELY, D. 2001; DARGAY, J. et al. 2007).

Urban development has been a contemporary process of population migration from rural to urban areas. This transformation implies an increasing proportion of the population living in cities and urban settlements. The increase of population and density transform urban areas in large agglomerations that need highly complex requirements for passengers and freight mobility between a multitude of origins and destinations. When urban zones become high density areas, mobility is a central issue in the urban transport system.

There are two extreme forms of urbanization: high density and spread-out. Usually metropolitan areas merge the two forms, with a dense compact central transit-oriented downtown and central business districts CBDs surrounded by scattered, sprawling large spread-out auto oriented suburbs. There are areas in the city with high density of population and services where public mass transit means prevail, and large urban areas with low density where private vehicles are the dominant modes of transport.

More people moving within greater metropolitan areas implies increased travel distances, usually covered by private vehicles. The rapid growth of suburban areas has been accompanied by a profoundly growth in car ownership, more than public transport, because in less dense metropolitan areas only cars allow high accessibility, in front of public transport. The increasing car use changes conditions of the traffic circulation within metropolitan areas.

The accelerated pace of urbanization and the affordability of motorized mobility tends to 
lead to traffic congestion in densely populated cities. The increasing use of cars contributes to raise the costs of travel and the negative consequences: traffic congestion, parking constraints and disorder, accidents, air pollution.... Higher costs of car travel, coupled with public policies to deter car use and an increasing supply of more efficient public transport, tends to favor modal shifts from car to public transport and in some regions also to motorcycle. When this stage is reached, car ownership enters a phase of slow decline, in which income levels tend to identify more for higher quality and lower age of the fleet, than by its size. Increasing fuel prices and parking fees will also lead to made more competitive PTW than cars in urban areas.

The pace of motorization tends to be faster that the capability of infrastructures and facilities to improve the efficiency of transport systems, resulting in a problem of congestion, and an increase of travel times. Congestion tends to reduce the mobility of auto users. High population density at urban residential areas affects negatively car ownership (YAMAMOTO, T. 2009). Urban congestion negatively affects transit, increasing travel times, declining for public transport users (GAKENHEIMER, R. 1999).

In dense urban areas massive car use is related with pollution, problems in the interactions between vehicles and pedestrians and parking restrictions. To attenuate these problems several kinds of policies are implemented to discourage car use: restricting traffic in the center where large pedestrian zones are created, taxes to car access to different urban areas. Different levels of vehicle taxation affects to the choice of vehicle type, consumption, emissions (BIRKELAND and JØRGENSEN (2001).

The restriction of car use favors the use of less bulky vehicles like the PTW. Policies of major cities in advanced countries aim to limit the use of cars in urban areas. In urban dense areas increases the attractiveness of motorcycles thanks to its greater ease of travel with heavy traffic, less parking constraints and lower consumption (Chin, A. and . SMITH, P. 1997).

In advanced societies high income allows people to have more leisure time (OECD 2014). In these societies the offer of leisure activities is more varied and sophisticated. One of the options is to use the motorcycle for recreational purposes. In many cases ride motorcycles, possession and collection are related with social and leisure activities. Motorcycling activities are doing for the sake of travelling in order to perform leisure activities. A substantial number of motorcycle travels are related to leisure activities and are influenced by economic conditions, weather, and recreational opportunities. In U.S. recreation is the top reason cited by people for riding motorcycles (GHSA 2011). Only about $33 \%$ motorcyclists consider using their vehicle as a primary mean of transportation to drive to/from work or school (McCARTT et al. 2011). In the other side in some Asian countries as Taiwan only 4,9\% of trips are for recreational purpose (HSU, T.-P, et al. 2003). 
At last stage of motorization evolution, the increased use of motorcycles in dense urban areas is based on three factors: motorcycles are more competitive in urban areas with traffic and parking restrictions, sociologically the incorporation of women increases the use of PTW and finally in areas with high purchasing power and enough leisure time, recreational use motorcycle appeared with a renewed interest, mostly in weekend and spare time (HAWORTH, 2012).

\section{MODELING PRIVATE VEHICLE OWNERSHIP EVOLUTION}

The rapid increase of motorization in the world improves transport and economy, but it is also associated with negative externalities (accidents, pollution and congestion). Modeling vehicle ownership is a powerful tool useful to analyze and predict scenarios that assist decision-making and transport planning.

There are different model approaches, among others: aggregate, disaggregate, heuristic, discrete-continuous, pseudo-panel methods, and dynamic (de JONG 2004). Disaggregate models based in econometric discrete choice analysis are useful to model the microeconomic individual choice behavior that conforms the consumer demand for transport services. However modeling the evolution number of vehicles per household is a macro level analysis, done using aggregate models based in time series approach of large zones information (country, region, city) of household aggregated data. Different types of studies use empirical data and mathematical models based in several kinds of socio-economic and demographic characteristics attributes: income, density, population, costs, access, fuel prize, transportation system, land development type ..., aiming to estimate vehicle ownership to help in the transportation planning process.

Aggregate models have lowest data requirements. Many vehicle ownership aggregate models, mostly by country, have been carried out attempting to model the demand as a function of socio-demographic, economic, transportation system, and land development characteristics. (TANNER 1962 and 1983; BATES et al. (1978); BEESLEY, M.E. and KAIN, J. (1964); BUTTON et al (1993); WHELAN et al., 2000, WHELAN, 2001), DARGAY and GATELY 1999. INGRAM and LIU (1997) found significant relationship between number of vehicles and road lengths, and estimate the quantitative relationship with incomes, population, urbanization and fuel prices.

Overall private motor vehicle ownership is the sum of cars and PTWs. The models of car and motorcycle ownership are different but not independent. Car and motorcycle ownerships shape mobility and the evolution of private vehicle possession are closely interrelated, even with cross elasticity, but with different shapes.

The evolution of vehicle ownership models use to relate a dependent variable as volumes of vehicles in function of an economic type independent variable as per-capita income, gross 
domestic product (GDP), per-capita GDP. The model use to represent a long-term growth with several periods, mostly linked with different stages of economical devolvement.

When population arrives to a particular basic threshold of per capita income people can afford buying motorized vehicles. The cheapest vehicles are mopeds and motorcycles, and therefore they are the first motor vehicle to be acquired. When the income increases people can afford to buy cars, that are globally preferred for its versatility, security, comfort and status, appearing a substitution effect in the election between car and PTWs. At higher levels of per capita income, the substitution effect decreases by the possibility to own several types of vehicles. In this way relationship between motorcycle and car ownerships differs depending of level of the economy and other factors gain relevance, as urbanization, transport policies, security and leisure.

\subsection{Modeling car ownership}

There is a long tradition of studies that model the evolution in the level of car ownership and relevant variables. Car ownership models are based in one or several independent variables related with economic evolution, urbanization form and transport policies.

The relationship between measured economic values and car ownership variables is nonlinear in the long-term. It is usually assumed that the equation that well describes the data is a sigmoid-shape function, an S-shape curve. (TANNER 1958; MOGRIDGE, M. J. H. 1967). The flexible Gompertz function allows to relate vehicle/population ratio with an economic variable (ZACHARIADIS, T. et al 1995; TALUKDAR, D. 1997; INGRAM and LIU 1999; WANG, M., et al. 2006). Examples are the work done during a long period in UK and 18 industrialized countries from 1958 to 1980, founding a strong relationship between car ownership and the rate of economic and of income levels on the number of cars, and how income elasticity decline as countries incomes increase (TANNER,J.C 1983). Vehicle ownership models in low income countries have similarities with industrial states reinforcing the importance of income effect in car ownership and traffic volume expansion as income countries prosper (BUTTON et al. 1993).

The model must represent three perio ds: a initial period of fairly steadily growth resulting of a sluggish economic growth until it reaches a threshold point, starting a boom period where income afford buying cars encouraging an abrupt change, with a sharp increase in a relatively short time arriving at a level of saturation, giving way to a third plateau period where hardly grows number of vehicles per capita and even inconvenient discourage use, since then the tendency is a stabilization with a smoothly growth or even a slightly recession. The function has two inflexion zones: the first place the expansion levels, the second inflexion zone starts a asymptotic area, determining the saturation level of vehicle ownership. The shape is fitted on adjustable parameters.

Analyzing the behavior of the evolution of car ownership is important to note two important 
phenomena: the inelasticity of car ownerships at high income levels (saturation threshold) and a hysteresis loop back, in the way that car ownership does not respond symmetrically to rising and falling income (DARGAY, J. 2001).

DARGAY, J. and GATELY, D. carry on international comparisons studies analyzing the relationship between car ownership and income levels using data, in a previous study from 26 countries (1999) and extending the range to 82 countries (2001). They used a Gompertz function to represented the long-run equilibrium level of the vehicle/population ratio $V_{t}^{*}$ (Vehicle ownership in year i) as a function of per capita income GDP, allowing to predict the motorization rate (the number of cars per 1,000 persons). The equation can be written as:

$$
V_{t}^{*}=\gamma e^{\alpha e^{\beta G D P_{t}}}
$$

Where the parameter $\gamma$ is the saturation level that cannot be equal to 0 . The parameters $\alpha$ and $\beta$ are two negative values that determine defining the shape, or curvature, of the $S$-shape function of vehicle ownership over economic growth.

Income elasticity shows how a low level of income, motor-vehicle ownership acts as a "normal good" increasing demand as income rise for per capita motor-vehicle ownership, and conveyed a threshold of saturation, as people increase income vehicle demand is more and more elastic. In the Gompertz curve long-run elasticity is estimated by appropriate differentiation:

$$
\eta_{t}^{L R}=\gamma \beta G D P_{t} e^{\beta G D P_{t}}
$$

In order to account for lags in the adjustment of vehicle ownership to per-capita income, postulated a partial adjustment mechanism:

$$
V_{t}=V_{t-1}+\theta\left(V_{t}^{*}-V_{t-1}\right)
$$

Where $\theta$ is the speed of adjustment $(0<\theta<1)$ and $V t$ is vehicle ownership at time $t$.

The adjustments follow some slow and gradual socio-economic and urbanistic changes, that aggregate in the model produces the resulting equation:

$$
V_{t}=\gamma \theta e^{\alpha e^{\beta G D P_{t}}}+(1-\theta) V_{t-1}
$$

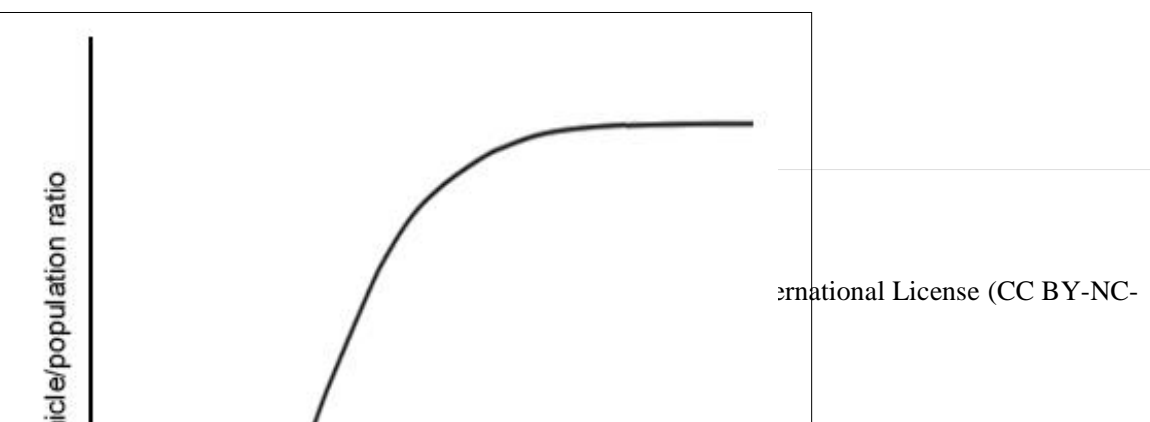


Figure. 1. Gompertz function

Initially DARGAY, J. and GATELY, D. (1999) presume that within a given income level, car ownership will remain similar between countries. Subsequently DARGAY, J. and GATELY, D. (2011), considered that vehicle saturation levels must not be similar for all countries, because differences across them make likely to reach saturation at different income levels. That is possible because not only the economic variable is relevant, been also relevant the influence of transport policies and urbanization forms, which vary from one country to another and geographical area. Many factors influence motorization and transport policies is a prominent one.

Differences between countries in political and economic institutions matters, and explain some differences in economic growth and prosperity. Democratic institution oriented to accomplish population demands are more sensible to respond to increasing public pressure towards better provision and more efficient transport system. The result is that, democratic and advanced countries tend to be more willing and able to channel resources into transport system efficiency and higher quality of life standard that implies restrict the use of private vehicles in urban areas. When income grows in developing countries, if public transport is not promoted and there is no intervention policy, car use increases without public transport alternatives, rising traffic congestion. Public transport availability is closely related with car ownership. (KUTZBACH, M.J 2009; BUTTON et al. 1993).

On this way must be consider different income elasticity depending of population density, urban structure and transport policies, declining saturation level of vehicles per capita as population density increases. The curve has similar shape but there are four different patterns depending on the geographical area: North American \& Australia, Europe and Asia and lower vehicle ownership (HUO, H., et al. 2007). The form remains particularly common during the initial period before reaching the threshold of transition. One of the factors that can explain the differences is the different process, intensity and features on which countries have made the transition from a rural society to an urban society. In North America it has been a very progressive step without practically no megacities and large urban areas with 
low density. However several countries in Asia (Japan, South Korea, Taiwan, Thailand, Malaisa and later China, Vietnam and the Philippines) have experienced one fast transition from rural to urban modern dense areas. After the Civil War, sixty years ago South Korea was one of the poorest countries in the world with much of the population living in agricultural communities, nowadays $90 \%$ of the population lives in urban areas (CHANG, H. 2007).

\subsection{Modeling PTWs ownership}

In a long-term perspective, the relation between economic prosperity and motorcycle possession is less strong than car ownership. Motorcycle use is influenced by many different factors from car use, implying a different type of ownerships evolution. The relationship between income and PTWs possession appears to be non-linear: at the beginning, economic growth leads to a growing number of PTWs, but later more prosperity tends to mean fewer motorcycles and more cars.

Otherwise, in some advanced countries, driving motorcycles has a high recreational purpose, influenced by factors as culture, spare time availably, weather, risk-perception and demographic structure, more than economic factors. This fact subtracts weight to the purely economic variables, taking part a wider range of explanatory variables. Since the mid-1990s, notable increases in motorcycling use in developed countries are related with a wide range of activities with motorcycles for commuting and recreational (JAMSON, S. and CHORLTON, K. (2009); McCARTT, A. T., et al. (2011); HAWORTH, N. (2012).

The evolution of possession of PTWS in relation to per capita income should show how as a country develops and people have higher incomes want to improve their mobility acquiring mechanical modes that allow more accessibility at lower prices. The motor vehicle most accessible are mopeds and low power motorcycles. PTWs are a form of personal transport that can provide to individuals an affordable means of transport and cheaply mobility opportunities for acquisitions, operation and park.

At the first stages of economic growths, PTWs ownerships increases at the income pace, until it reaches a wealth level when people could afford buying cars, and prefer then, procuring a modal split, declining motorcycle possession as income rise further. Therefore as income rise and per capita wealth exceeded a certain threshold that allow people buying cars, people shifted from motorcycles to car ownership, declining not the global but the relative number of PTWs in relationship with cars. At low levels of income, PTWs behaves as "normal good", increasing consumption with wealth. But in relation with cars PTWs acts as "inferior goods", thus at higher income levels, substitution effects appears from motorcycles to cars that are preferred as "superior good" with higher attributes.

In dense urban areas, increase of motorization and massive car use produces congestion and parking problems. PTWs use could help for reducing traffic congestion, giving opportunities 
to cities to use less area for motor vehicles and parking. In this specific situation and areas, in developed countries, where car motorization expanded, it tends to get reduced and increase the use of TPWs.

The S-shaped Gompertz function valid for represent car evolution does not provide a statistically fitted representation of the relationship between evolution of GPD per capita and number of PTW; specially for countries with fast growing economies like East Asian Countries (China, Japan, Malaysia, Taiwan and Vietnam). In Australia, New Zealand and Japan motorcycle ownership level grow with the economy and then decline when income reached a certain level (SILLAPARCHARN, P 2007). In the case of evolution of car ownership the high correlation with wealth growth facilitates to formulate models related with economic variables. At the starting stages of economic development PTWs ownership increases at the pace of economy, but reaching an advance level of per capita income, other variables have significance as safety, availably and recreational use.

Research studies suggest that the relationship between motorcycle ownership and per capita income growth follows a long-term inverted U-shaped curve, which fits relationship between PTWs ownership and economic development. The function was formulated by Simon Kuznets (i.e., the Kuznets curve) (1955) in the framework to represent the relationship between environmental pollution and per capita income, trying to show how development gives rise to some structural socio-economic transformation in what an economy produces (GROSSMAN, G.M., and KRUEGER, A.B. 1995).

The inverted form pretends to show how at early stages of economic growth PTWs have positive attributes, but with the society transformations that progress produces, decreases the tolerance of negative externalities of PTWS and lose appeal.

This dual and opposing effect could be explained because the structural changes that occur in the society and urban forms when economy grows, lead to changes in the transport model pressures in the long-term. Development allow motor vehicles use as PTWs because his affordability, but increase motorization entails adverse impacts as accidents that may split consumers preferences and induce structural urban transformation, and when increases population affordability to buy motor and at same time transform consumers preferences (from PTWs to cars when can afford to buy).

Over time, the scale of the socio-economic activity entails negative impacts of PTWs (mainly increase of accidents), and such urban structural transformation may, reverse the expected positive relationship between economic development and PTWs use (HSU, T (2007).

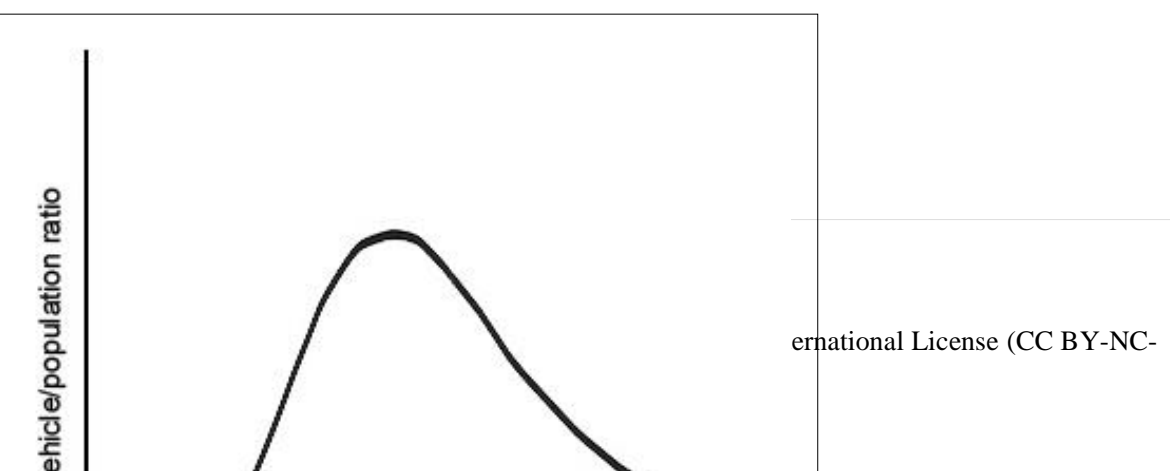


Figure. 2. Kuznets function

Different models of PTWs ownership has been formulated with some type of inverse Ushape curve. SILLAPARCHARN, P (2007) formulated for Thailand a model where motorcycle ownerships increase until reach a threshold, after that motorcycles ownership declines replaced by car ownership, been the equation:

$$
\begin{aligned}
& \log \mathrm{MC}_{1000}=\mathrm{a}^{+} \mathrm{b}_{1} \log \mathrm{GPPpH}_{i}+\mathrm{b}_{2}\left(\log \mathrm{GPPpH}_{i}\right)^{2}+\mathrm{b}_{3} \text { Distance }_{i} \\
& +\mathrm{b}_{4} \log \mathrm{C} 1000_{i}+\mathrm{b}_{5}(\log \mathrm{C} 1000)^{2}
\end{aligned}
$$

Where:

$$
\begin{aligned}
& \text { MC } 1000_{i}=\text { The number of motorcycles per } 1000 \text { inhabitants for province } i \\
& \text { POP } 1000_{i}=\text { The selected as a weight variable } \\
& \text { GPPpH }_{i}=\text { Gross provincial product per household for province } i \\
& \text { Distance } i=\text { Linear distance of province } i \text { from Bangkok } \\
& C 1000=\text { Number of car per } 1000 \text { inhabitants for province } i \\
& a, b_{1}, b_{2}, b_{3}, b_{4} \text { and } b_{5}=\text { Coefficient of influencing variables }
\end{aligned}
$$

Taking in consideration the former model, PONGTHANAISAWA, $\mathbf{J}$ and SORAPIPATANA, Ch (2010) consider that SILLAPARCHARN, P (2007) underestimated the motorcycle ownership after trespassing the peak; formulating a new model based in a logistic function taking as a dependent variable overall vehicle ownership (vehicles per 1000 persons) at year $t\left(V_{\text {overall }, t}\right)$.

$$
V_{\text {overall }, t}=\frac{S}{1+e^{a} \cdot G_{t}^{-b}}+c \cdot D_{t}+\varepsilon_{t}
$$

Where:

$S=$ Saturation level of the overall vehicle ownership (vehicles/1000 inhabitants)

$G_{t}=$ per capita GDP at year $t$

$D_{t}=$ as a dummy variable in year $t$

$a, b$, and $c=$ coefficients of the model 


$$
\varepsilon_{t}=\text { error term }
$$

The results allows to forecast a transition from motorcycle to car ownership calculating the motorcycle ownership peak by number of vehicles and per capita GDP, showing as overall private vehicle ownership in Thailand is similar to most developed countries.

Using data for a large panel of vast majority of countries for the period 1963-2010 NISHITATENO, S. and BURKE, P. J. (2014) pointed to a Kuznets-style inverted U-shaped relationship between average income levels and motorcycle ownership. So that at low income levels, possession of motorcycles grows at the same pace until reaching an income level from which an inflection occurs and decreases the possession of motorcycle as income increases. The curve shape tends to be more pronounced in densely populated countries.

LAW, T.H. et al. (2015) have done a cross-country statistics analysis using sample data of 80 countries at various levels of economic developmental growth over the 48-year period between 1963 and 2010, considering the interaction between motorcycles and car ownership and how the associated proportion was influenced by the growth of economic development in the countries, determining the relationship between the motorcycle to passenger car (MPC) ownership ratio and the per capita Gross Domestic Product (GDP). The study finds an inverted U-shaped relationship between the motorcycle to passenger car (MPC) ownership ratio and the per capita Gross Domestic Product (GDP). Generally, the MPC ownership ratio increased with income at a lower level and decreased with income at a higher level. The resulting function take as dependent variable the motorcycle to passenger carowernship per a country $i$ at year $t\left(\mathrm{MPC}_{i, t}\right)$.

$$
\ln \left(\mathrm{MPC}_{i, t}\right)=\alpha_{i}+\varphi_{1} \ln \left(\mathrm{GPD}_{i, t}\right)+\omega_{2}\left(\ln \left(\mathrm{GPD}_{i, t}\right)\right)^{2}+\varphi \mathrm{year}_{i, t}+\beta^{\prime} x_{i, t}+\varepsilon_{i, t}
$$

Where:

$\mathrm{GPD}_{i, t}=$ per capita GDP in country $i$ at year $t$

$\alpha_{i}=$ The country-specific intercept

$\varphi, \omega$ and $\beta=$ Model parameters to be estimated.

$x_{i,}=$ A vector of other explanatory covariables.

$\varepsilon_{i, t}=$ Is a error term.

In a country where motorcycle use expand fast DAO, N.X. and DUC, NH (2005) use a multiple linear regression to the motorcycle ownership level at the national level for Vietnam, as multinomial logistic regression for motorcycle ownership for individual ownership and household ownership (LEONG and FARHAN). HSU, T. et al. (2007) uses a Poisson regression form to model the motorcycle ownership of household, as a function where dependent variable $\mathrm{Y}$, number of occurrences $(\mathrm{k})$ of an event, has a Poisson distribution given the independent variables $\mathrm{X} 1, \mathrm{X} 2, \ldots, \mathrm{Xm}$; founding that the owning number of motorcycle decreases when increases the number of licenses, cars and household members using public transportation, showing directly substitution effect among motorcycle and public transportation and car mode. 
The inverted U-shaped curve is also useful to show the relationship between traffic fatality risk and per capita income. The curve fits how accidents first increase and then decrease with income. Thereby can explain the phenomenon that as income increases the acquisition and use of motor vehicles lead to increased accidents, which make people become aware of the danger and stimulate safety mechanisms. Therefore as incomes rise, governments and individuals devoted more resources to invest in safer vehicles and in road safety, driving a decline in the fatality rate (VAN BEECK, E.F. et al. 2000; KOPITS, E. and CROPPER, M. 2005).

DUFFY, M. and ROBINSON, T., 2004 made an econometric analysis of motorcycle ownership in the UK and conclude that motorcycle use will not decrease in the long-term , on the contrary, the future growth prospects may be quite good. In dense urban areas, cars will experience increasing cost of running because of for further tolls, taxes and environmental restrictions, favoring a substitution effect from car to motorcycles. The conclusion of the analysis implies questioning that in the long run high incomes are related with declining use of the motorcycle, and therefore that the model of PTWs ownership fits an inverted U-Shape. 


\section{THE EVOLUTION OF PRIVATE MOTOR VEHICLE OWNERSHIP IN SPAIN.}

The first motor vehicle registered in Spain dates October 31, 1900. Figure 3 shows the evolution of vehicles registered annually (passenger cars and motorcycles, excluded mopeds), from the beginning of the available register of motor vehicles dating 1900, until year 2014. However, registers of mopeds are only available from year 1987 to 2015. It is possible to find some similarities between the model of private vehicle ownerships evolution and the Spanish motorization process, identifying the big stages of the model: a long starting period form beginning until Spanish Civil War and post-war of sluggish increase with prevalence of motorcycles over cars, a period of rapid expansion driven by the popularization in the use of car, and a third period of stabilization and saturation level in car use.

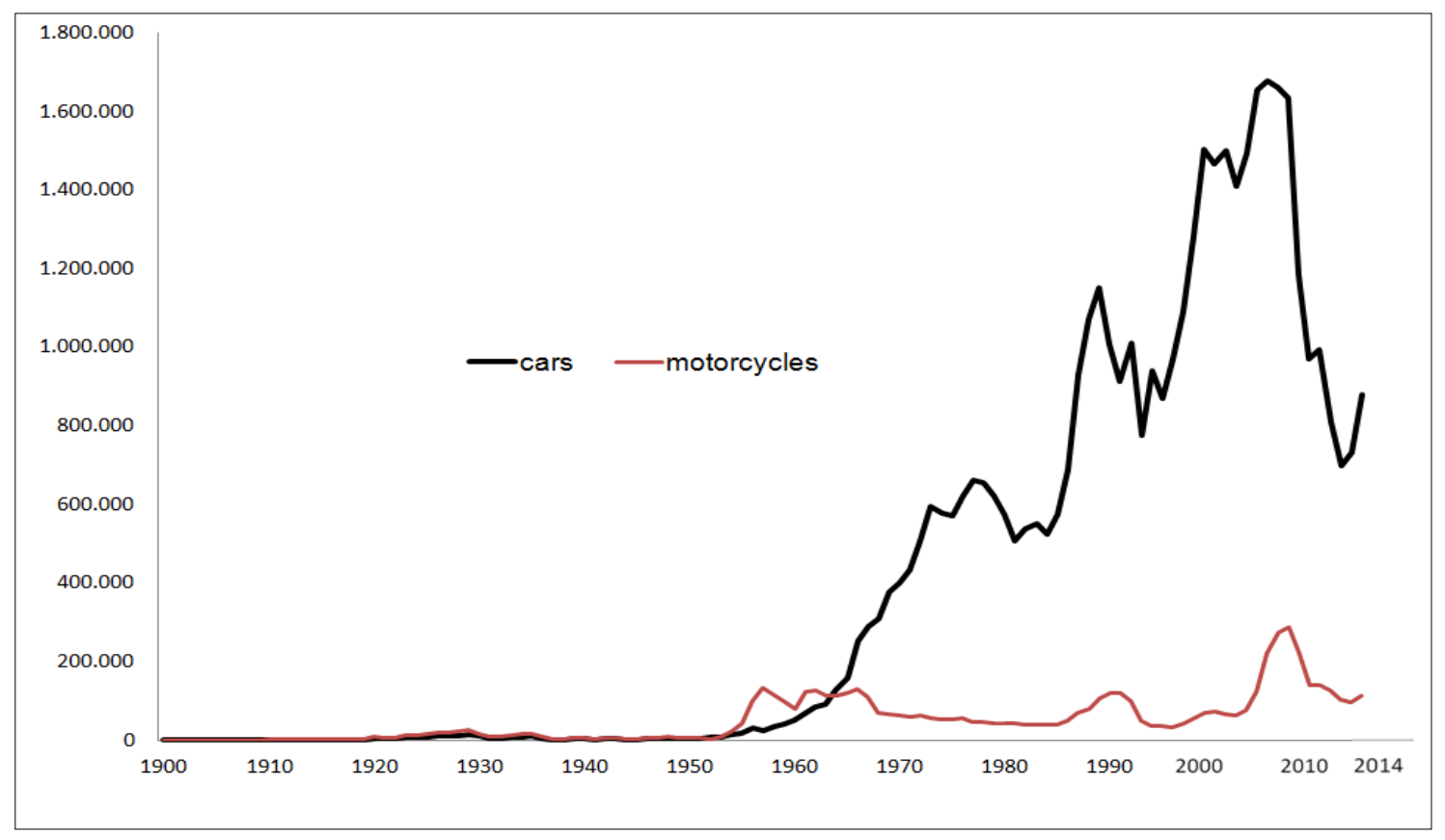

Figure 3. Evolution of vehicle registration (total cars and motorcycles)

The beginning covers a long period from the start of the century until the half of the 1950s, of sluggish increase of vehicle possession at the pace of the economy and vehicles industry innovation. The first vehicle was registered in Spain in 1900, with a total of 4 vehicles registered for the end of the year. In 1901, 47 vehicles were registered, most of them in the seaside resort of San Sebastian, as the car was an exponent vehicle snobbery of a high economic level linked to leisure. The automotive industry began in Spain in 1903, although during the first half of the century a big part of the cars were imported. At the very beginnings cars are luxury items, and the main vehicle is the bicycle. As purchasing power increases, motorcycle ownership expands rapidly, with a slow car registration. This long period low increase of registrations goes at the pace of economy, with periods of economic stagnation as after the big crisis of 1929 , when vehicle registration decreased. The main characteristic 
of the period is that the volume of vehicle registration is low, been much larger the number of motorcycle's (a ratio of three to one). This period suffered a long stagnation because economic turbulences during the Spanish republic, civil war and long recession along the post-war period.

Spanish Civil War (1936-1939) led to a severe long post-war economic crisis, extending a period in low level of purchasing power. During this first stage of evolution, motorcycles were the most affordable motor vehicle, and remained more registered than cars until the year 1967.

As some studies have noted, during first stages of historic evolution income is primary factor of vehicle ownership, declining elasticity as countries incomes increase (TANNER ,J.C 1983; BUTTON et al. 1993; DARGAY, J. and GATELY, D. 2009). During this period of low purchasing capacity there is a high elasticity between salaries and vehicle purchasing. Motor vehicle behaves as a "normal good". In this regard in 1957 some governmental policies allow a general lift of wages without a increase of prices, resulting in a purchasing power improvement, leading an augmentation of motorcycle registration in that very year. In the subsequent years the increase of inflation neutralized the effect of wage increase, which resulted in a contraction in motorcycle registrations.

The second period of historical motor vehicle evolution in Spain could be located in the second half of the 1950s. It is characterized by the expansion of motorization. The negative economic consequences of the Civil War remain until the year 1959, when the government launches a series of "Stabilization Plans", intended to promote the well-being and progress through the implementation of the package of specific actions such as technological improvement and industrial development.

The expansion period of motorization is favored largely by the government's commitment to the domestic car industry. As many countries, Spanish government perceived the automotive industry as a strategic sector. As a capital and labor intensive industry, this sector requires strong investments, skill work force and technology, that contributes to increase employment, national production and raise the technological level. The large magnitudes of the sector facilitate upstream and downstream activities. The government intervention tried to promote and protect domestic industry helping production at low prices to stimulate the purchase of cars that increase the motorization. In the 1953 was founded the enterprise SEAT, the flagship of Spanish car industry, one year after French industry Renault starts producing vehiclesin Spain, followed by oter enterprises as Pegaso, Barreiros, D. K. W., Simca, Dodge.

One of the fundamental instruments of planned economy is the manufacture of vehicles. The Development Plan 1963 set ambitious targets for domestic vehicle production. Several policies introduced government-subsidized programs to reduce cars prices and accelerating car acquisition. As the car industry is granted exemption reducing final price the incentive 
to own a car will increase accordingly. Various studies explain a similar phenomenon with the automotive and motorcycle in Japan, China, Vietnam, Thailand and Malaysia (FUJITA , M. 1998; 2013).

The expansion period experienced a momentum of car registrations during the period 19601966 with a five-fold increase, passing from 50,254 to 250,673. This augmentation in car registration is directly related to the $65 \%$ increase in per capita income, which went from 16,247 to 25,306 currency units (FLORES GIMENEZ, F. 1969).

The registered number of car surpassed motorcycles in 1967. In 1966 the number of motorcycles are 1,210,496 in front 1,052,506 cars; passing the next year to 1,259,062 motorcycles against 1,334,837 cars. In 1963, motorcycles accounted for $53.7 \%$ of the vehicle fleet and three years later descent to $44.3 \%$. This decrease is related to the strong increase in income per capita. The automobile domestic industry expand inside the national market: in 1962 the 14,2\% of cars were imported, passing to be 5,6 \% in 1966, because increases in the official protection to domestic production. At the same tine road infrastructures expand and improve: in 1960 there were a total of 130,645 kilometers of road and no one of highway; in 1983 the road have a length of 150,256 kilometers and motorways 2,763. In a period of 10 years there was a sharp increase in car use that reduced the percentage weight of the use of the motorcycle as a vehicle for long distance transportation. In the year 1960 the $12,8 \%$ of road passenger trips were made in motorcycle, reducing until only $1,4 \%$ by the year 1980 (IETC 1992).

Economic expansion tends to generate an increasingly affluent middle class, for whom the automobile reaches full popularity, becoming an indicator of the purchase power. In the decade of 70 ' the number of vehicle registrations nearly tripled, although the economic growth stabilized at around 6\%. The oil crisis started in 1973 by a severe oil prices increase, affecting the economic growth, but on the contrary it did not stop the private vehicle registration that kept on the ascent trend with fluctuations. The growth period lasted the decade of the 1980s with an average growth rate above $8 \%$. In the next decade there were signals of deceleration, between 1990-1999, the annual average growth rate descent to $4.3 \%$, been the half of observed in the preceding decade.

The third period of historical vehicle evolution could be located passing the half of the $2000 \mathrm{~s}$ decade. This period is characterized because motorization achieve saturation level, from which follows a slowdown and decrease. In Spain, the increase of the number of vehicle registration remained until the year 2006. In 2007 starts the big economic crisis and vehicle registration suffer a severe descent with average rate of $-18.5 \%$ in the period 2007-2009. Since 2008 the Spanish economy is installed in a long period of crisis with a continuous descend in the number of vehicle registration only stopped in 2014 when cars demand was stimulate by a policy of lower prices (prices in the automotive sector back to 2003 levels), and governmental aid programs. During this period it's possible to observe a substitution effect from cars to motorcycles. While car registrations fall sharply, the motorcycles are 
maintained and, since the year 2010, increase. Another effect of the crisis is that during the period 2007-2012 the average age of vehicles has increased 2.5 years since 7,8 to 10,3 years old. (ANFAC 2012).

Figure 4 shows evolution of the rate of motorization (vehicles per 1,000 inhabitants). It is possible to identify stabilization in a range 660-685 vehicles/population during the period 2006-2012 (DGT 2012). The rate of motorization in the range of 675 vehicles per 1,000 inhabitants is congruent with the estimates of the studies of DARGAY and GATELY that in 1999 made assumptions and projections of vehicle ownership for Spain of 710 vehicles per 1,000 people for the year 2015. The same study predicts a rate of 550 cars per 1,000 inhabitants, been the real ratio in a range of 475 vehicles per 1,000 inhabitants for the period 2006-2012 (EUROSTAT 2014). For the group of 15 member States of the European Union (named E-15), among which is Spain, the rate of motorization varies between 385 and 618 cars per 1,000 inhabitants. In saturation levels, it is no obvious the relationship between rates of motorization and wealth. The different motorization between EU-15 countries has to be explained by different territorial structures, transport policies, weather, culture and lifestyles. In this sense HUO, H. et al (2007) contemplate that in Europe the correlation between per capita GDP and motorization is slower than that of the North American pattern, partially attributable to the denser population and compact urban development in European countries, considering that the saturation level for the European growth pattern is about 600 vehicles per 1,000 inhabitants.

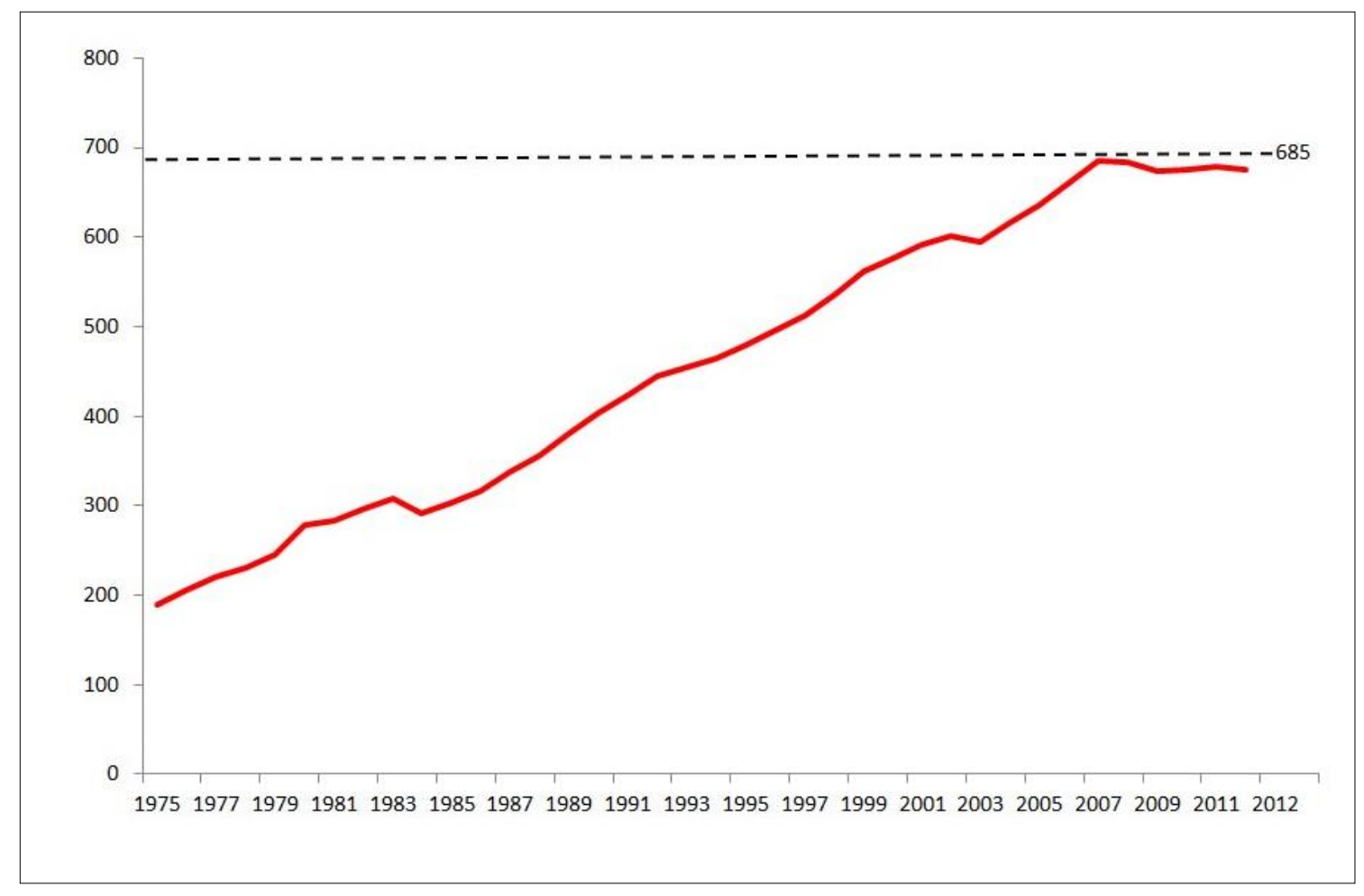

Figure. 4: Car ownership evolution in Spain (vehicles per 1,000 inhabitants) 
The loss in purchasing power resulting from the 2007 crisis implies a reduction of cars acquisition. The life of the cars is prolonged, causing a sharp increase in the average age of cars on the road. In the period 2007-2011 the vehicles have gone from an average life of 7 years to 11 years. (ANFAC 2012).

Analyzed the whole evolution of private vehicle ownership in Spain, motorcycles have a strong proportion at the beginning, but car ownership gradually has been gaining predominance, surpassing in 1965 the total number, broadening differences, currently obtaining a large proportion of the overall private vehicles.

Another pattern in evolution of private vehicle ownership in Spain is that it is closely linked with economic growth, according to mainstream theories and models. Several studies have found high correlation between motorization and economic development. TORREGO SERRANO, F. (1987) analyzes provincial rates of motorization and finds correlation between fleet and GDP per capita, being lower in rural than urban areas. GADEA, M. D and MONTAÑES, A. (2009) formulate this explanatory model of the evolution of the volume of vehicle registrations based in GPD corrected by interest rate as explanatory variable:

$$
\log (\operatorname{REGISTRATION})=\beta_{1}+\beta_{2} \cdot \log (\mathrm{GPD})+\beta_{3} \cdot \log (r)+\mathrm{u}
$$

Where:

$$
\begin{aligned}
& G P D=\text { Spanish GPD } \\
& r=\text { Interest rate Euribor per a year } \\
& \mathrm{u}=\text { Random perturbation } \\
& \beta_{1}, \beta_{2}, \beta_{3}=\text { elasticity coefficients }
\end{aligned}
$$

The determinants setting are indicators as GDP and interest rate. The results will make predictions about the evolution of registration, so when the Spanish GDP increased by $1 \%$ , the number of registrations increased by $\beta_{2} \%$. And when the Euribor increases the number of registration decrease by $\beta_{3} \%$

When the evolution of cars and motorcycles is analyzed separately, is possible to find a good fit with the models for cars evolution, rather than in the case of motorcycle evolution. The evolution of cars fits a curved S-shape (U.S Gompertz). It can be seen a long period of slow growth, an area of inflection and a period of faster expansion until reaching saturation levels. It is possible to establish a zone of saturation at 670 vehicles/1000 inhabitant; quite similar with the number predicted by DARGAY and GATELY (1999).

Figure 5 shows the historical evolution of the total park of cars and motorbikes. Since 1962 are real data and backwards are simulated from registrations. The relevance of the figure is observe the shapes of the line of evolution, being able to perceive as cars rise rapidly and reach a saturation level while motorcycles have a increasing tendency with peaks and peaks and troughs. 


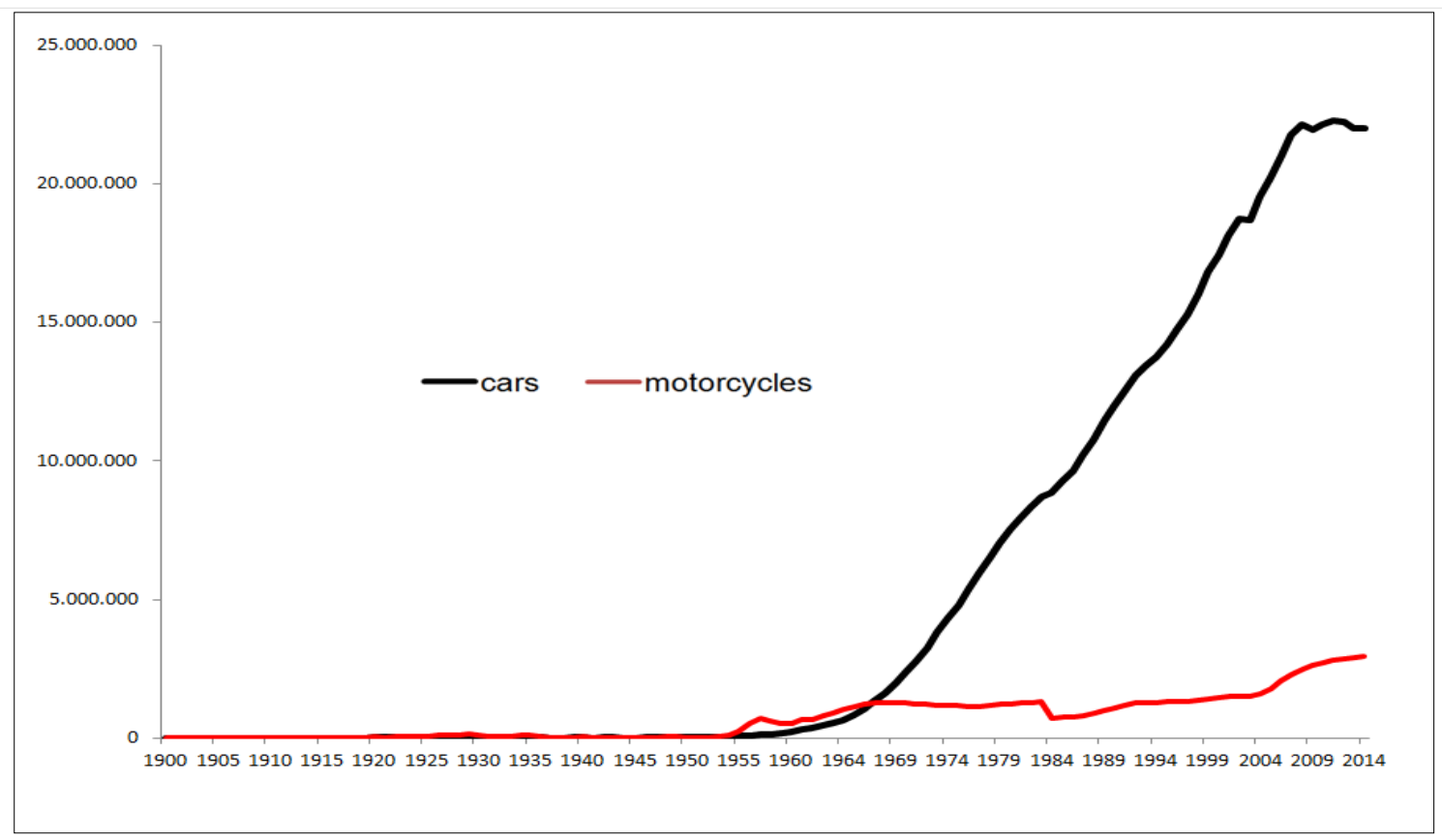

Figure. 5: Estimated evolution of cars and motorcycle fleet (vehicles).

The evolution of motorcycle ownership during the initial an expansion periods shapes a Uinverse curve (i.e. Kutznet), but during the post-expansion period, the decline in motorcycle use is not maintained, experiencing continuous peaks and troughs, with an upward trend. Since the car has reached its saturation period the increasing of use of motorcycle denotes substitution effects between car and motorcycle, especially in dense urban areas where the cost of using the car has increasing significantly. The result is that the evolution doesn't well fit a U-inverse curve.

Figure 6 shows how in some European countries PTWs ownership increases, in line with the PTWs ownership evolution in Spain, reinforcing the consideration that cars saturation levels are accompanied substitution effects form cars to PTWs.

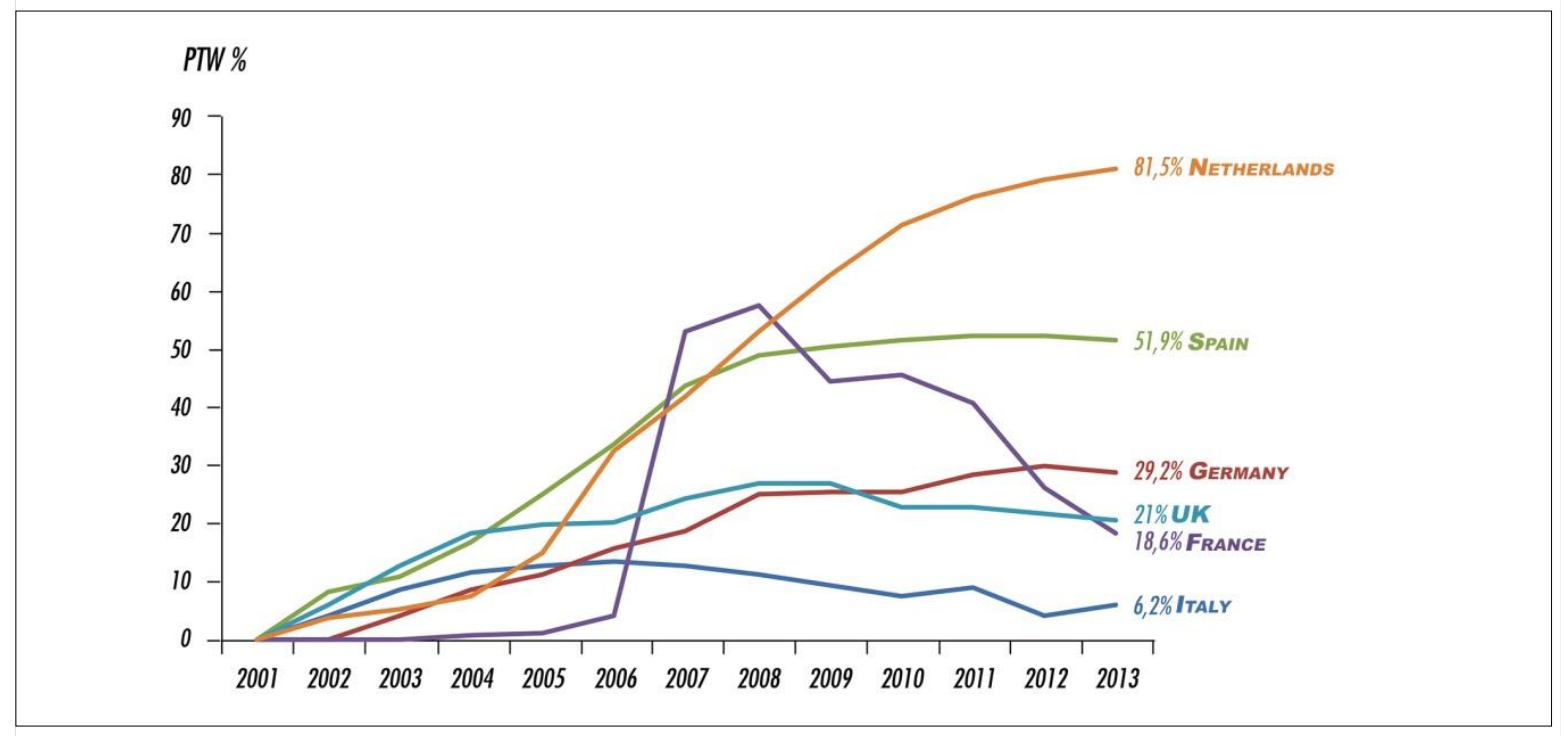

Figure. 6: Evolution of stock of registered PTW from 2002 to 2013 (\%) 


\section{THE STAGE IN WHICH IS THE CITY OF BARCELONA}

Barcelona is one of the densest cities in the world. One million six hundred thousand inhabitants are distributed in a small area, which also attract a high number of journeys, generated by a substantial socio-economic activity. In addition, in the last 10 years the surface for private vehicle-circulation has been reduced by $10 \%$, there have been implemented restrictions to private car use, increasing length of lanes exclusively devoted to bus and bikes, and regulating car parking on road.

Figure 7 shows the evolution of the rate of motorization (vehicles per 1,000 inhabitants) in the city of Barcelona. From 1996 to 2010 the number of vehicles augmented in a rate of 6,000 vehicles per year: increasing 900,000 to 980,000. During 2000-2003, there was a small decrease in the fleet, followed by a recovery. In 2007 there was the maximum number of vehicles, 991,151. In 2009 begins stabilization, followed by a continuous declining of the fleet. It is possible to identify stabilization in range 600-620 vehicles per 1000 inhabitants, then decrease (AJUNTAMENT DE BARCELONA 2016a).

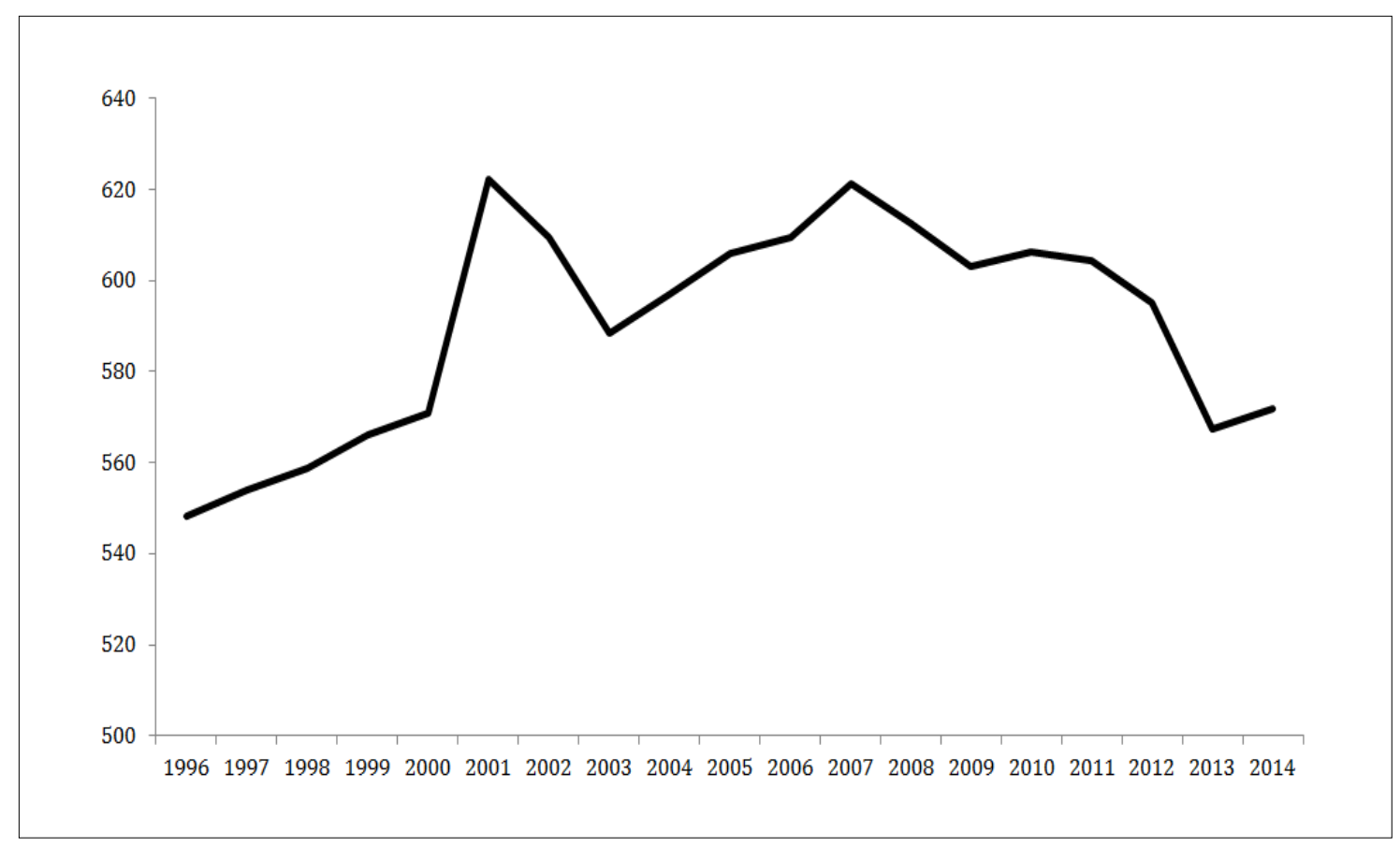

Figure. 7: Evolution vehicles per 1.000 inhabitants in Barcelona

Despite the high density, Barcelona does not lead the rankings of European urban congestion areas (TOMTOM 2015). One of the factors that allows a daily significant volume of motorvehicle journeys in such a dense space is that a large percentage of internal journeys are made by motorized two-wheelers. PTWs accounts for $17.4 \%$ of mobility in private vehicles in the city of Barcelona (AJUNTAMENT DE BARCELONA 2012).

The evolution by types of vehicles shows a tendency of decrease in cars fleet, whereas those PTWs tend to rise. People travel less by car, changing and increasing the use of PTWs. The use of motorized two-wheeled vehicles is a growing phenomenon. Small dimensions, high 
maneuverability and free parking on streets, have made of PTWs a competitive mode of transport in terms of cost and time, and have additionally contributed to relieve traffic conditions. In 15 years (1996-2014) the number of PTWs per 1000 inhabitant has increased by $21 \%$, while cars have decreased by $15 \%$. In 2012 the $34 \%$ of non-commercial vehicles in Barcelona were motorized two-wheelers.

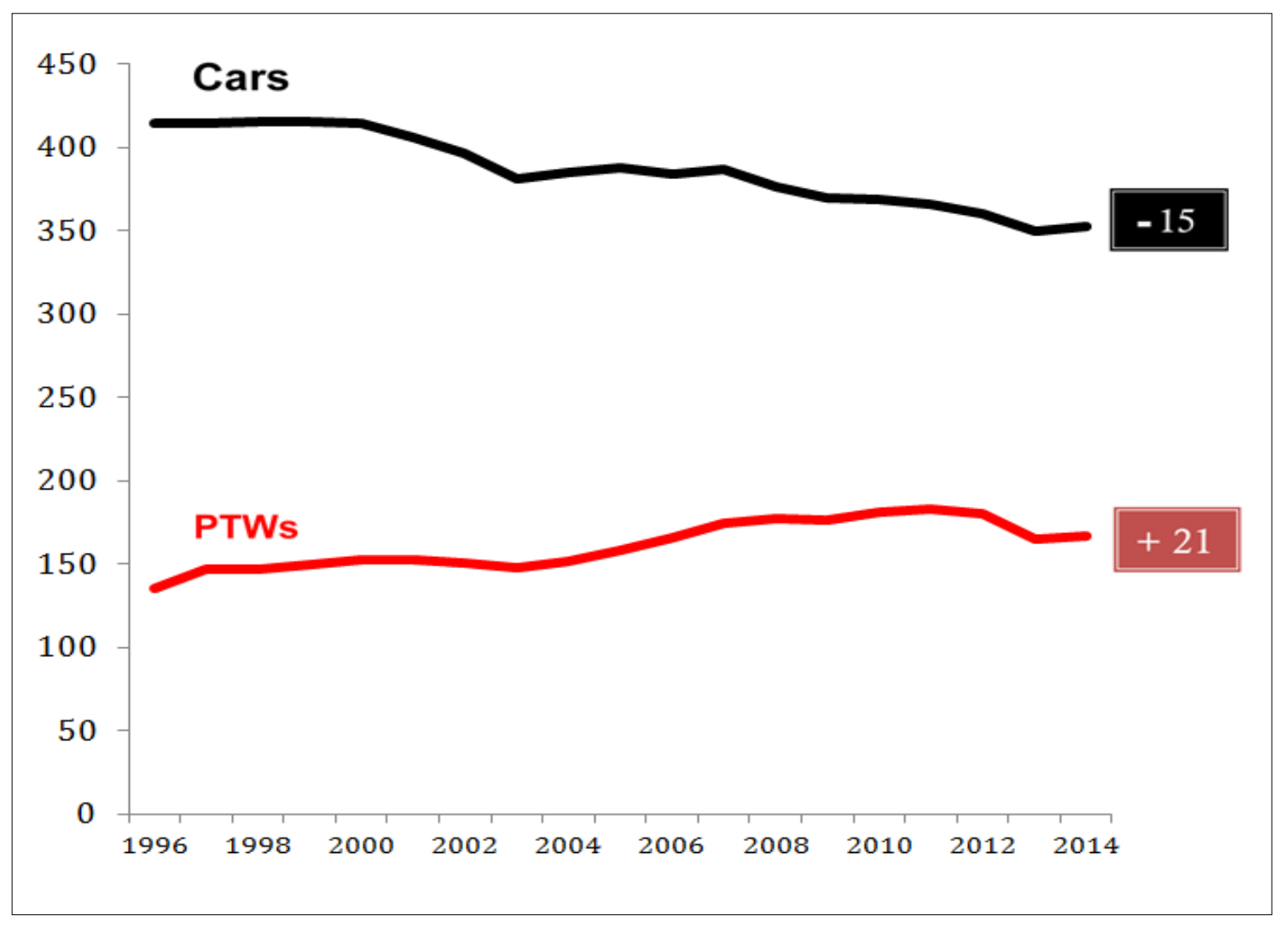

Figure.8: Evolution of stock of Cars and PTWs in Barcelon from 1996 to 2014 (\%)

As many European metropolitan areas Barcelona experiences a double trend: major tertiarization of the center city and increasing journey attraction and population decentralization from center city to peripheries. The implications are that major population living distantly form work centers became more car dependence for access to jobs (MATAS, A. et al. 2009); and major number of journeys in congested center town, favors a that Barcelona has a high level of dependence on motorcycle vehicles. Small size and high maneuverability make PTWs more convenient for inner city trips especially during traffic congestion periods.

Barcelona is in a stage of maturity in the field of urban transport policies. The indicators of vehicle possession are similar to other highly developed countries, having reached a level of saturation in the number of cars per capita. The city has high motorization rates and also high number of trips by private vehicles despite having a good and efficient public transport offer.

Mobility policies are a feature of advanced societies, addressed to promote public transport 
and bicycles, discourage the use of private vehicles, especially cars, and less PTW. Traffic calming schemes has been implemented in Barcelona. Pedestrian and slow velocity areas have been extended, and bicycle use has been promoted. There is a successful public bicycle renting system (Bicing) and it has been planned in a three-year horizon (from 2015 to 2018) to triple the length of bicycles lanes from 118 to $308 \mathrm{~km}$; seeking to increase the share of bicycle use mode 1.5 to $2.5 \%$ (AJUNTAMENT DE BARCELONA 2015).

In Barcelona, congestion pricing has been introduced by an indirect way. Instead of implementing urban toll schemes, the main set of measures to price car use has been through regulatory parking policies and increasing cost on street car parking. Unlike car parking pricing implantation, on street motorcycle parking has no cost, and it is allowed and free on sidewalks. In addition, the numbers of on street motorcycles parking places are in augmentation. Congestion pricing have a significant effect on encouraging motorcycle use, assuming motorcyclists were not charged for parking.

Those traffic calming schemes have discouraged the use of car, partially shifting the use of cars for the motorcycles. Besides, governments have taken actions to discourage car use, and measures to favor PTWs such as increase parking spaces for motorcycles, creation of advanced Stop Lines at traffic lights, improved traffic safety of motorcycles using anti-slip paint for road markings and reducing the crosswalks painted area. Altogether it has favored the reduction of the inefficiencies associated with traffic congestion and increased attractiveness for PTW use.

As in Barcelona, many European local governments in major cities implement policies to inhibit and reduce car use, targeting relieve congestion and emissions of greenhouse gases. In this sense they have implemented actions to restrict car use that intentionally, or unintentionally, have favored PTWs and bicycles use because the small size and nimbleness of those vehicles reduces congestion. To favor bus public transport some measures are implemented to escape the congestion caused by massive presence of cars, separating circulation of buses in independent lanes. In Barcelona, transit lanes reduce private-vehicle space of circulation, and tend to increase congestion, a fact that also favors the shift from car use to PTWs.

The increasing use of PTWs involves negative externalities. In Barcelona, motorcyclists remain the most vulnerable road users, been the group with the largest number of serious injuries and deaths. In 2015 63\% of killed in accidents in the city of Barcelona were motorcyclists. The probability of having a fatal accident in Barcelona travelling in PTW is 12.5 times higher than in a car, and for the case of serious injuries it is twenty times higher (AJUNTAMENT DE BARCELONA 2016b). The high density of Barcelona and saturated streets increase safety conditions, because congestion diminishes the probability of suffering severe injuries, finding negative relationship between traffic flow (congestion) and injury severity of PTW (ALBALATE, D.; FERNÁNDEZ-VILLADANGOS, L. 2010). 
Increase use of PTWs is a common phenomenon among major European cities. Since the mid-1990s there has been a continuous increase in PTWs ownership and their use in large European cities. In Paris in the period 2000-2007 PTWs has experienced an increase of 36 $\%$ and prívate cars a decrease of $23 \%$ (KOPP, P. 2009). Motorcycle traffic appears to have been increasing notably in Greater London since the introduction in 2003 a pricing scheme "The Congestion Charge", granting exemption to PTWs has benefit a notably increase of use and posseison of PTWs in London Area. In Rome motorcycles represent $16 \%$ of vehicles in circulation and have increased by $60 \%$ between 2002 and 2014 (AUTOMOBILE CLUB D'ITALIA (2014).

Those trends suggest a continuous future growth of PTWs use in urban congested areas, showing a relevant income elasticity of demand for motorcycles and substitution effect from car, and even from public transport to PTWs in stages of high economic levels. The increasing use of PWTs in developed countries congested urban areas may contradict the models interrelating economic growth and the use of the motorcycle. 


\section{CONCLUSIONS}

Transport systems provide mobility necessary for human socio-economic activities. Journeys made by private vehicles (mainly cars and powered two wheelers PTW) make up an important part of mobility. Understanding about patterns of the historic evolution of motor vehicle ownership is useful to forecast future transport scenarios. The knowledge about how motorization evolves assist in decision making over policy implementation, transport planning, investment decisions, building infrastructure, regulation, energy consumption and assessing transport programs to help maximize social welfare.

The historical evolution of private vehicle ownership is determined by different types of variables, mostly related with per capita income, urbanization, public policies and alternative means of transport.

Consumer preferences about modes of transport change according to the stage of motorization evolution. The elasticity between PTWs and car ownership evolves over different levels of income: at low levels, motorization increase mainly through the acquisition of PTWs, when income gets to the threshold at which people can afford to buy cars, a substitution effect from PTWs to cars appears. The last stage is when societies reach high incomes and an advance socio-economic stage, where the rate of motorization tends to reach a saturation level, shifting from an expansion market to a mature one, where the demand of vehicles stops increasing, despite income continuing to rise.

The saturation level can be measured by the number of vehicles per 1,000 inhabitants, and varies depending on the type of society and geographical and urbanization factors. At advanced stage, in dense urban areas, despite motorization tending to decrease, it is possible to find an increase in PTWs use, because the PTWs smaller dimensions facilitate journeys in saturated areas with traffic and parking restrictions.

Vehicle ownership models are a useful tool for analyzing and predicting scenarios that assist decision-making and transport planning. The relationship between measured economic variables and car ownership is non-linear in the long-term, fitting a sigmoid-shape function. The Gompertz function represents the long-run equilibrium level of the vehicle/population as a function of per capita income. The S-shaped Gompertz function that is valid to represent car evolution doesn't provide a statistically fitted representation for the PTWs. Studies suggest that a long-term inverted U-shaped curve (i.e., the Kuznets), fits better for the relationship between PTWs and per capita income. The double slope shapes the PTWs increase at early stages of economic growth ownership and once a threshold level is surpassed, higher incomes produces the inverted effect, declining the use of PTWs. The inverted U-shaped curve is also useful to show the relationship between PTWs traffic fatality risk and per capita income. 
Some other studies and this one, suggest that in advanced European countries PTWs use will not necessarily decrease in the long-term. In dense urban areas, cars experience increasing operational cost because of tolls, taxes, parking and environmental restrictions, favoring a substitution effect from car to more convenient PTWs. Those future growth prospects, questioning the inverted U-shaped model consider that in the long run high per capita incomes are related with declining use of motorcycles. This study also notes that in a highdensity city like Barcelona the trend is an increase in the use of PTWs.

Having analyzed the whole evolution of private vehicle ownership in Spain, the private vehicle ownership evolution is closely linked with economic growth. Analyzed separately, the evolution of cars fits a curved S-shape (U.S Gompertz) according with mainstream theories and models. A long period of slow growth can be seen, an area of inflection and a period of faster expansion until saturation levels are reached. It is possible to establish a zone of saturation in the 670 vehicles/1000 inhabitant; quite similar with the number estimated by DARGAY and GATELY (1999). In contrast, the evolution of motorcycle ownership in the initial stage shapes a U-inverse curve (i.e. Kutznet), but after reaching the peak, the decline in motorcycle use is not continuous, experiencing peaks and troughs, with an upward trend. This kind of evolution does not fit the models based on U-inverse curves (i.e. Kuznet). These evolution explains that once cars have reached saturation levels, it is possible to observe substitution effects between cars and PTWs in dense urban areas, as in the City of Barcelona where cars operational cost has increased significantly.

Barcelona is one of the densest cities in the world. Mobility policies are characteristic of an advanced society, addressed to promote public transport and bicycles. Congestion pricing has been indirectly implemented by with street car parking schemes. Actions to restrict car use, intended or unintended, have favored the shift from car use to PTWs. In fact, Barcelona is a city that is highly dependent on motorcycles. Small size, high maneuverability, low operational costs and free on-street parking made PTWs more convenient for inner city trips. In 15 years (1996-2014) the number of PTWs per 1,000 inhabitant increased by $21 \%$, while the number of cars has fallen by $15 \%$.

Increase use of PTWs in Barcelona is a common phenomenon in major European cities: Paris, London and Rome. These trends suggest a continuous future growth of PTWs use in urban congested areas, showing a relevant income elasticity of demand for motorcycles and substitution effect from car and even public transport to PTWs.

The increasing use of PWTs in developed countries and congested urban areas is not in line with the assumptions of the U-inverted curves models, which predict that in the long-run there will be a decrease in use of PTWs with high income per capita levels. These results may suggest that conducting further research might be helpful in analyzing possible functions that improve modelization of PTWs ownership in advanced stages of socioeconomic development, considering that the curve shape can acquire a growing slope. 


\section{REFERENCES}

AJUNTAMENT DE BARCELONA (2012). "Pla de Mobilitat Urbana PMU 2013-2018”.

AJUNTAMENT DE BARCELONA (2015). "Estratègia de la bicicleta". Dossier de prensa.20 noviembre 2015.

http://premsa.bcn.cat/wp-content/uploads/2015/11/151120-Dossier-estrat\%C3\%A8gia-biciDEFINITIU3222.pdf

AJUNTAMENT DE BARCELONA (2016a). Departament d'Estadística

http://www.bcn.cat/estadistica/angles/index.htm

AJUNTAMENT DE BARCELONA (2016b). “Balanç accidentalitat 2015”. Dossier de prensa. 14 de enero 2016.

http://premsa.bcn.cat/wp-content/uploads/2016/01/2016_01_14-Accidentalitat-2015.pdf

ALBALATE, Daniel; FERNÁNDEZ-VILLADANGOS, Laura (2010) "Motorcycle Injury Severity in Barcelona: The Role of Vehicle Type and Congestion", Traffic Injury Prevention, 11: 6, 623-631

ALONSO, W. (1964). "Location and Land Use. Toward a General Theory of Land Rent". Harvard University Press, Cambridge, MA.

ANAS, Alex; ARNOTT, Richard; SMALL, Kenneth A. (1998). "Urban spatial structure". Journal of Economic Literature, p. 1426-1464.

ANFAC (2012). Asociación Española de Fabricantes de Automóviles y Camiones "Mercado y parque de turismos en españa evolución y potenciales". ANFAC Research

AUTOMOBILE CLUB D'ITALIA (2014). Dati e statistiche "Veicoli e mobilità".

http://www.aci.it/laci/studi-e-ricerche/dati-e-statistiche/veicoli-e-mobilita.html

BAUM-SNOW, Nathaniel. (2007). "Suburbanization and transportation in the monocentric model”. Journal of Urban Economics, vol. 62, no 3, p. 405-423.

BEESLEY, Michael E.; KAIN, John F. (1964). "Urban form, car ownership and public policy: an appraisal of traffic in towns". Urban Studies, vol. 1, no 2, p. 174-203.

BIRKELAND, M.E.J.; JORDAL-JØRGENSEN (2001). "Energy Efficiency of Passenger Cars", Paper presented at the European Transport Conference 2001, PTRC, Cambridge.

Brueckner, Jan K. (1987). "The structure of urban equilibria: A unified treatment of the Muth-Mills model". Handbook of regional and urban economics. Vol. 23, no 2, p. 160-171.

BUTTON, K.; NGOE, N.; HINE, J. (1993). "Modelling vehicle ownership and use in low income countries". Journal of Transport Economics and Policy, 1993, p. 51-67

CHANG, Ha-Joon. (2007). "Bad Samaritans: The myth of free trade and the secret history 
of capitalism”. Bloomsbury Publishing USA.

CHIN, Anthony; SMITH, Peter. (1997). "Automobile ownership and government policy: The economics of Singapore's vehicle quota scheme". Transportation Research Part A: Policy and Practice, 1997, vol. 31, no 2, p. 129-140.

DARGAY, Joyce M. (2001). "The effect of income on car ownership: evidence of asymmetry". Transportation Research Part A: Policy and Practice, 2001, vol. 35, no 9, p. 807-821.

DARGAY, Joyce M.; GATELY, Dermot (1999). "Income's effect on car and vehicle ownership, worldwide: 1960-2015". Transportation Research Part A: Policy and Practice, 1999, vol. 33, no 2, p. 101-138.

DARGAY, Joyce M.; GATELY, Dermot (2001). "Modelling global vehicle ownership". In Proceedings of the Ninth World Conference on Transport Research. 2001. p. 22-27.

DARGAY, Joyce M.; GATELY, Dermot and SOMMER, Martin (2007). "Vehicle Ownership and Income Growth, Worldwide: 1960-2030” The Energy Journal, 2007, p. 143170.

de JONG, G.; FOX, J.; DALY, A. and PIETERS, M. (2004). "A comparison of car ownership models". Transport Reviews, 24(4), 379-408.

DGT. Dirección General de Tráfico. (2012). “Anuario estadístico General. Año 2012”. http://www.dgt.es/Galerias/seguridad-vial/estadisticas-e-indicadores/parque-vehiculos/series-historicas/2012.pdf

DUFFY, Martyn; ROBINSON, Terry (2004). "An econometric analysis of motorcycle ownership in the UK". International Journal of Transport Management, , vol. 2, no 3, p. 111-121.

DULANEY, William L. (2005) “A brief history of 'outlaw' motorcycle clubs". International Journal of Motorcycle Studies, 2005, vol. 1, no 2.

http://ijms.nova.edu/November2005/IJMS_Artcl.Dulaney.html

EUROSTAT. European Commission Daba Base (2014). "Passenger cars per 1000 inhabitants" Code: road_eqs_carhab

http://ec.europa.eu/eurostat/web/products-datasets//road_eqs_carhab

FISHMAN, Robert. (2008). "Bourgeois utopias: The rise and fall of suburbia" . Basic Books.

FUJITA, Mai (1998). "Industrial Policies and Trade Liberalization-The Automotive Industry in Thailand and Malaysia". The Deepening Economic Interdependence in the APEC Region. Tokyo: APEC S. Center, Institute of Developing Economies, p. 149-187. 
FUJITA, Mai. (2013). "The Motorcycle Industry: The Global Context and the Vietnamese Case". In Exploiting Linkages for Building Technological Capabilities. Springer Japan, 2013. p. 9-19.

FUJITA, Mai. (2014). "Exploiting Linkages for Building Technological Capabilities: Vietnam's Motorcycle Component Suppliers under Japanese and Chinese Influence”. Springer Science \& Business Media.

FUJITA, Masahisa. (1989) “Urban economic theory: land use and city size”. Cambridge university press.

GADEA, María Dolores; MONTAÑES, Antonio (2009). "Situación y perspectivas del sector del automóvil en España” en Anuario de Movilidad 2009 RACC.

GAKENHEIMER, Ralph. (1999). "Urban mobility in the developing world." Transportion Research A, Vol. 33, no. 2.

GALSTER, G.; HANSON, R.; RATCLIFFE, M. R.; WOLMAN, H.; COLEMAN, S.; FREIHAGE, J. (2001). "Wrestling sprawl to the ground: defining and measuring an elusive concept”. Housing policy debate, volume 12 Issue 4, 681-717. Fannie Mae Foundation.

GHSA (2011). Governors Highway Safety Association. HEDLUND, James. "Motorcyclist Traffic Fatalities by State” Washington DC

http://www.ghsa.org/html/files/pubs/spotlights/spotlight_motorcycles11.3.pdf

GÓMEZ, Julián; ACEVEDO, Jorge (2013). "Studying Car and Motorcycle Ownership Levels in Developing Countries Using Individual Income Distributions". In 13th World Congress on Transport Research, Rio de Janeiro, Brazil. 2013.

GOODWIN, P.B. (1997). Mobility and car dependence. In: ROTHENGATTER, T.; VAYA, E.C. (eds.) "Traffic and Transport Psychology”, pp. 449-464. Pergamon, Oxford.

GROSSMAN, G. M.; KRUEGER, A. B. (2002). Economic Growth and the Environment, Quarterly Journal of Economics, CX, May, 353-77. International Library of Critical Writings in Economics, vol. 141, p. 105-129.

GUERRA, Erick. (2015). "The geography of car ownership in Mexico City: a joint model of households' residential location and car ownership decisions". Journal of Transport Geography, vol. 43, p. 171-180.

HAWORTH, N. (2012). "Powered two wheelers in a changing world-Challenges and opportunities". Accident Analysis \& Prevention, vol. 44, no 1, p. 12-18.

HICKMAN, R.; FREMER, P.; BREITHAUPT, M.; SAXENA, S. (2011). "Changing Course in Urban Transport: An Illustrated Guide”. Asian Development Bank. Deutsche 
Gesellschaft für Internationale Zusammenarbei

http://www.adb.org/sites/default/files/publication/29352/changing-course-urban-transport-illustrated-guide.pdf

HSU, Tien-Pen. (2005). "Comparative study on motorcycle ownership forecasting model of Asian countries-Taiwan, Malaysia and Vietnam". The 6th International Conference of Eastern Asia Society for Transportation Studies, Bangkok; 2005.

HSU, T.P.; AHMAD, F. M.S.; and DAO, N. X. (2003). "A comparison study on motorcycle traffic development in some Asian countries-case of Taiwan, Malaysia and Vietnam". The Eastern Asia Society for Transportation Studies (EASTS), International Cooperative Research Activity.

HSU, T.P.; TSAI, Chia-Chia; LIN, Yu-Jui (2007). "Comparative analysis of household car and motorcycle ownership characteristics". Journal of the Eastern Asia Society for Transportation Studies, 2007, vol. 7, p. 105-115.

HUO, Hong; WANG, M.; JOHNSON, L., \& HE, D. (2007). "Projection of Chinese motor vehicle growth, oil demand, and CO2 emissions through 2050". Transportation Research Record: Journal of the Transportation Research Board, (2038), 69-77.

IETC. Instituto de Estudios del Transporte y las Comunicaciones (1992). "Los transportes y las Comunicaciones: Anuario 1992”. Madrid 1992

INGRAM, Gregory K.; LIU, Zhou. (1997). "Motorization and road provision in countries and cities”. World Bank Policy Research Paper, , no 1842.

http://siteresources.worldbank.org/INTURBANTRANSPORT/Resources/wps1842.pdf

IRTAD (2014). International Transport Forum. Database, October http://www.internationaltransportforum.org/irtadpublic/pdf/roaduse.pdf

JAMSON, Samantha; CHORLTON, Kathryn (2009). "The changing nature of motorcycling: Patterns of use and rider characteristics". Transportation Research Part F: Traffic Psychology and Behaviour, , vol. 12, no 4, p. 335-346.

KA IO, Wong (2013). "An Analysis of Car and Motorcycle Ownership in Macao", International Journal of Sustainable Transportation, 7:3, 204-225, DOI:

KOPITS, Elizabeth; CROPPER, Maureen (2005). "Traffic fatalities and economic growth". Accident analysis \& prevention, vol. 37, no 1, p. 169-178.

KOPP, Pierre (2009). "The contribution of two-wheel motor vehicles (2WMV) to mobility in a big city The case of Paris (2000-2007)”. Panthéon-Sorbonne university.

KUTZBACH, Mark J. (2009). "Motorization in developing countries: Causes, consequences, and effectiveness of policy options". Journal of Urban Economics, 2009, vol. 65, no 2, p. 154-166. 
LAW, Teik Hua; HAMID, Hussain; GOH, Chia Ning. (2015). "The motorcycle to passenger car ownership ratio and economic growth: A cross-country analysis". Journal of Transport Geography, vol. 46, p. 122-128.

LEE, Tzu-Chang; POLAK, John W.;.BELL, Michael G.H., and WIGAN, Marcus R. (2011). "The kinematic features of motorcycles in congested urban networks". Accident Analysis \& Prevention, 49, 203-211.

LEONG, Lee Vien and AHMAD, F. M.S. (2007). "A study on the motorcycle ownership: A case study in Penang State, Malaysia”. Proceedings of the Eastern Asia Society for Transportation Studies. Eastern Asia Society for Transportation Studies, 2007. p. 84-84.

LITMAN, Todd. (2015). "Transportation affordability: evaluation and improvement strategies". January 2015 Todd Litman Victoria Transport Policy Institute. http://www.vtpi.org/tdm/tdm106.htm

MATAS, Anna; RAYMOND, José-Luis; ROIG, José-Luis (2009). "Car ownership and access to jobs in Spain”. Transportation Research Part A: Policy and Practice, 2009, vol. 43, no 6, p. 607-617.

McCARTT, A. T.; BLANAR, L.; TEOH, E. R.; and STROUSE, L. M. (2011). "Overview of motorcycling in the United States: a national telephone survey". Journal of Safety Research, 42(3), 177e184.

MIESZKOWSKI, Peter and MILLS, Edwin S. (1993). "The causes of metropolitan suburbanization”. The Journal of Economic Perspectives, , p. 135-147.

MILLS, Edwin S. (1967). “An aggregative model of resource allocation in a metropolitan area”. The American Economic Review p. 197-210.

MILLS, Edwin S. (1972). "Studies in the Structure of the Urban Economy". The Economic Journal. Vol. 83, No. 329 (Mar., 1973), pp. 289-291

MOGRIDGE, M. J. H. (1967). "The prediction of car ownership". Journal of Transport Economics and Policy, p. 52-74.

MOHAN, Dinesh, (2002). "Traffic safety and health in Indian cities". Journal of Transport and Infrastructure, vol. 9, no 1, p. 79-94.p. 52-74.

MONCLÚS, F.J. (1998). "Suburbanización y nuevas periferias. Perspectivas geográficourbanísticas". In the book MONCLÚS, F.J. (Ed.): "La ciudad dispersa”. Centre de Cultura Contemporania de Barcelona, 1998, p. 5-15.

MUTH, Richard F. (1969). "Cities and housing; the spatial pattern of urban residential land use”. Chicago, IL: University of Chicago Press, 1969. $355 \mathrm{p}$ 
NISHITATENO, Shuhei; BURKE, Paul J. (2014). "The motorcycle Kuznets curve". Journal of Transport Geography, vol. 36, p. 116-123.

OANH, N.T.K.; PHUONG, M.T.T. and PERMADI, D.A. (2012). "Analysis of motorcycle fleet in Hanoi for estimation of air pollution emission and climate mitigation co-benefit of technology implementation". Atmospheric Environment, 2012, vol. 59, p. 438-448.

OECD (2014). "Balancing paid work, unpaid work and leisure. Time use across the worldTime spent in unpaid work and leisure" OECD based on data from National Time Use Surveys"OECD Publishing. http://www.oecd.org/gender/data/OECD 1564 TUSUpdatePortal.xls

PONGTHANAISAWAN, Jakapong; SORAPIPATANA, Chumnong (2010). "Relation-ship between level of economic development and motorcycle and car ownerships and their impacts on fuel consumption and greenhouse gas emission in Thailand". Renewable and Sustainable Energy Reviews, vol. 14, no 9, p. 2966-2975.

PRABNASAK, J.; TAYLOR, M. (2008). "Study on Mode Choice and Vehicle Ownership in a Medium-Sized Asian City". In The 30th conference of Australian Institute of Transport Research Proceedings (CAITR2008 Proceedings), University of Western Australia, Perth, Australia. 2008.

SCHAFER, Andreas. (2006). "Long-term trends in global passenger mobility". Frontiers of Engineering: Reports on Leading-Edge Engineering from the 2006 Symposium. 2007. p. 85.

SCHAFER, Andreas; VICTOR, David G., (2000). "The future mobility of the world population“. Transportation Research Part A: Policy and Practice 34 (3), 171-205.

SCHUSTER, Tassilo; HOLTBRÜGGE, Dirk. (2011). "Tata Nano: The car for the bottomof-the-pyramid”. In Fallstudien zum Internationalen Management. Gabler Verlag,. p. 83102.

SENBIL, Metin; ZHANG, Junyi; FUJIWARA, Akimasa (2007). "Motorization in Asia: 14 countries and three metropolitan areas". IATSS research, 2007, vol. 31, no 1, p. 46-58.

SILLAPARCHARN, Pattarathep (2007). "Vehicle ownership and trip generation modelling: a case study of Thailand". IATSS research, 2007, vol. 31, no 2, p. 17-26.

http://www.sciencedirect.com/sciencelarticle/pii/S0386111214602181

SRA: Swedish Road Administration Consulting Services (2008). "Trafikskador ur ett genusperspektiv". VVpublikation 2008.

STEG, Linda (2003). “Can public transport compete with the private car?”. IATSS Research, 27(2), 27-35.

STEG, Linda (2005). “Car use: lust and must. Instrumental, symbolic and affective motives 
for car use". Transportation Research Part A: Policy and Practice, 2005, vol. 39, no 2, p. 147-162.

STEG, Linda; VLEK, Charles; SLOTEGRAAF, Goos (2001). "Instrumental-reasoned and symbolic-affective motives for using a motor car". Transportation Research Part F: Traffic Psychology and Behaviour, 2001, vol. 4, no 3, p. 151-169.

STEVENSON, Mark; HARIZA, Ahmed (2006). "Mode choice model for vulnerable motorcyclists in Malaysia”. Traffic injury prevention, 2006, vol. 7, no 2, p. 150-154).

STRADLING, S. G.; MEADOWS, M. L.; BEATTY, S. (1999). "Factors affecting car use choices”. Transport Research Institute, Napier University, Edinburgh, 1999.

TALUKDAR, Debabrata (1997). "Economic growth and automobile dependence: is there a Kuznets curve for motorization?". Doctoral dissertation. Massachusetts Institute of Technology.

TANNER John Curnow (1962)."Forecasts of future numbers of vehicles in Great Britain". Roads and Roads Construction, vol. 40, pp. 263-74

TANNER, John Curnow (1978). "Long-term forecasting of vehicle ownership and road traffic". Journal of the Royal Statistical Society. Series A (General), 1978, p. 14-63.

TANNER, John Curnow (1983). "International comparisons of cars and car usage”. No. LR 1070 Monograph. Transport and Road Research Laboratory

TIWARI, R.; HERSTATT, C. (2014). "Role of Small Cars in India's Passenger Car Segment". In the book TIWARI, R; HERSTATT, C.s "Aiming Big with Small Cars". Springer International Publishing, p. 143-184.

TOMTOM (2015) “Tom Tom Traffic Index".

https://www.tomtom.com/es_es/trafficindex/\#/

TORREGO SERRANO, Florencia (1987). "El tráfico en España y las IMD de circulación en la red viaria" Anales de geografía de la Universidad Complutense. Servicio de Publicaciones, 635-644.

http://revistas.ucm.es/index.php/AGUC/article/view/AGUC8787110635A

TUAN, Vu Anh; SHIMIZU, Tetsuo (2005). "Modeling of household motorcycle ownership behaviour in Hanoi City". Journal of the Eastern Asia Society for Transportation Studies, 2005, vol. 6, p. 1751-1765.

VAN BEECK, Eduard F.; BORSBOOM, Gerard JJ; MACKENBACH, Johan P. (2000). "Economic development and traffic accident mortality in the industrialized world, 19621990”. International Journal of Epidemiology, 2000, vol. 29, no 3, p. 503-509. 
VERMA, Meghna (2014). "Growing car ownership and dependence in India and its policy implications". Case Studies on Transport Policy, 2014.

WHELAN, G. (2007). "Modelling car ownership in Great Britain". Transport. Res. Part A: Policy Pract. 41 (3), 205-219.

WHELAN, G., WARDMAN, M., DALY, A. (2000). "Is there a limit to car ownership growth? An exploration of household saturation levels using two novel approaches". In: Paper presented at European Transport Conference 2000, PTRC, Cambridge.

WU, G., YAMAMOTO, T., KITAMURA, R. (1999). "Vehicle ownership model that incorporates the causal structure underlying attitudes toward vehicle ownership". Transp. Res. Rec. 1676, 61-67.

YAMAMOTO, Toshiyuki (2009). "Comparative analysis of household car, motorcycle and bicycle ownership between Osaka metropolitan area, Japan and Kuala Lumpur, Malaysia. Transportation, 2009, vol. 36, no 3, p. 351-366.

ZACHARIADIS, Theodoros; SAMARAS, Zissis; ZIEROCK, Karl-Heinz. (1995). "Dynamic modeling of vehicle populations: an engineering approach for emissions calculations". Technological Forecasting and Social Change, 1995, vol. 50, no 2, p. 135149. 